\title{
The seismic history of the Pisia fault (eastern Corinth rift, Greece) from fault plane weathering features and cosmogenic ${ }^{36} \mathrm{Cl}$ dating
}

Silke Mechernich ${ }^{1}$, Sascha Schneiderwind ${ }^{2}$, Jack Mason ${ }^{2}$, Ioannis D. Papanikolaou ${ }^{3}$, Georgios Deligiannakis ${ }^{3}$, Aggelos Pallikarakis ${ }^{3}$, Steven A. Binnie ${ }^{1}$, Tibor J. Dunai ${ }^{1}$, Klaus Reicherter ${ }^{2}$

${ }^{1}$ Institute of Geology and Mineralogy, University of Cologne, Zülpicher Strasse 49b, 50674 Köln, Germany.

${ }^{2}$ Institute of Neotectonics and Natural Hazards, RWTH Aachen University, Lochnerstr. 4-20, 52064 Aachen, Germany.

${ }^{3}$ Laboratory of Mineralogy and Geology, Department of Natural Resources Development and Agricultural Engineering, Agricultural University of Athens, 75 Iera Odos Str., 11855

Athens, Greece.

Corresponding author: Silke Mechernich (mechernich.s@gmail.com)

\section{Key Points}

- Several earthquake horizons are revealed by mapping visual weathering features and terrestrial laser scanning (TLS) analysis

- At least six events with $25-110 \mathrm{~cm}$ of coseismic displacement $\left(\mathrm{M}_{\mathrm{w}} 6.2-6.7\right)$ ruptured the Pisia fault within the last $7.3 \pm 0.7 \mathrm{kyr}$

- The Holocene slip rate decreased from $0.8-2.3 \mathrm{~mm} / \mathrm{yr}$ (early Holocene) to 0.5 $0.6 \mathrm{~mm} / \mathrm{yr}$ (mid and late Holocene) 


\begin{abstract}
The deformation of the eastern Corinth rift (Greece) is distributed along several E-W trending active normal faults. Here, the 25-km-long Pisia fault experienced up to $150 \mathrm{~cm}$ of coseismic displacement during the 1981 Alkyonides earthquake sequence $(\mathrm{M}=6.7,6.4,6.3)$. Using terrestrial laser scanning, coupled with analyses of color changes, lichen colonization and karstic features, we identify differentially weathered horizontal stripes on the exposed Pisia fault plane. The stripe boundaries occur at scarp heights of $1.10 \mathrm{~m}, 2.05 \mathrm{~m}, 2.85 \mathrm{~m}, 3.60 \mathrm{~m}$, $4.15 \mathrm{~m}$, and $5.15 \mathrm{~m}$, with two additional possible boundaries at $3.10 \mathrm{~m}$ and $4.65 \mathrm{~m}$ (ca. $\pm 0.1 \mathrm{~m}$ respectively). This indicates that six to eight paleoearthquakes have exhumed the fault plane in a series of distinct coseismic slip events. A vertical profile of cosmogenic ${ }^{36} \mathrm{Cl}$ measurements is used to constrain age models of the exhumation. The results imply that, in addition to the last earthquake of 1981 (EQ1), exhumation events occurred at $2.0 \mathrm{kyr}$ (EQ2), $\sim 3.1 \mathrm{kyr}$ (EQ3), 4.5 kyr (EQ4/4a,b), 6.0 kyr (EQ5), and 7.3 kyr (EQ6/6a,b), with modeled age uncertainties of $\sim 0.7 \mathrm{kyr}$. Bayesian modeling provides a mid and late Holocene slip rate of $0.5-0.6 \mathrm{~mm} / \mathrm{yr}$ (last $7.3 \pm 0.7 \mathrm{kyr}$ ), while the upper part of the 8.45 -m-high fault plane was exhumed at a higher rate of $0.8-2.3 \mathrm{~mm} / \mathrm{yr}(7.3 \pm 0.7 \mathrm{kyr}$ to $10.2 \pm 1.9 \mathrm{kyr})$. This slip rate variability suggests an increased seismicity or larger slip events during the early Holocene.
\end{abstract}

\title{
1 Introduction
}

Active normal faults in carbonates are frequently preserved as bedrock fault scarps, particularly in the Mediterranean region. Their exhumation occurs periodically during cumulative surface rupturing earthquakes generating free-faces that are several meters high [e.g., Bosi, 1975; Stewart and Hancock, 1990; Armijo et al., 1992; Benedetti et al., 2002; Papanikolaou et al., 2005; Mason et al., 2016, 2017]. Recently in the Italian Apennines, the $\mathrm{M}_{\mathrm{w}} 6.0$ Amatrice earthquake ( $24^{\text {th }}$ August 2016) and the $\mathrm{M}_{\mathrm{w}} 6.5$ Norcia earthquake $\left(30^{\text {th }}\right.$ October 2016) exhumed an additional portion of up to $15-20 \mathrm{~cm}$ and up to $1-2 \mathrm{~m}$ of the respective fault planes [Livio et al., 2017; Pucci et al., 2017; Pizzi et al., 2017]. These earthquakes confirmed that the majority of coseismic deformation is accumulated on the bedrock free-face, as similarly shown for the 1981 Alkyonides earthquake sequences $(\mathrm{M}=6.7,6.4,6.3$; Corinth rift, Greece) [Jackson et al., 1982].

The periodic exhumation of the fault plane by distinct earthquakes results in differential grades of weathering (karstification, bio-erosion, degradation) [e.g., Giaccio et al., 2003; Carcaillet et al., 2008; Wiatr et al., 2015]. Therefore, the upper parts of fault scarps are usually characterized by more intense weathering in comparison to the base In addition, abrupt changes in fault plane features, such as colour contrast and micro-karstification features, can appear as discrete horizontal stripes [e.g., Wallace, 1984; Giaccio et al., 2003; Wiatr et al., 2015; Mildon et al., 2016]. In the past years such stripes were identified by color and roughness contrasts using different methods such as visual findings [Wallace, 1984; Caputo et al., 2004; Mildon et al., 2016], in-situ micro-roughness measurements [Stewart, 1996], photographic studies [Giaccio et al., 2003], rare-earth-element analysis [Carcaillet et al., 2008], and terrestrial laser scanning (TLS) [Wei et al., 2013; Wiatr et al., 2015; He et al., 2016]. TLS in particular has become an established tool to analyze fault scarps since it provides high spatial and temporal resolution data [e.g., Jones et al., 2009; Wilkinson et al., 2015, Mason et al., 2016; Cowie et al., 2017].

The most frequently applied technique for earthquake analysis on limestone bedrock fault scarps is exposure dating using cosmogenic ${ }^{36} \mathrm{Cl}$ [e.g., Zreda and Noller, 1998]. A regular and dense distribution of ${ }^{36} \mathrm{Cl}$ samples can be used to statistically determine the location of earthquake horizons on the fault plane using probability density functions [e.g., 
Schlagenhauf et al., 2010; Benedetti et al., 2013; Tesson et al., 2016]. The determined location of event horizons allows earthquake event ages to be calculated based on the temporal accumulation of ${ }^{36} \mathrm{Cl}$ concentrations.

In this study, paleoearthquake offsets of the Pisia bedrock fault scarp (eastern Corinth rift, Greece, Figure 1) are determined using a range of weathering features, and these earthquake horizons are then dated using ${ }^{36} \mathrm{Cl}$ exposure age dating. We evaluate the robustness of our coseismic displacement and earthquake age determinations and use the results to outline the earthquake recurrence intervals and slip rate variations of the Pisia fault.

\section{Seismotectonic context of the eastern Corinth rift and the Pisia fault}

The Corinth rift in Greece is $110 \mathrm{~km}$ long and $30 \mathrm{~km}$ wide and displays strong seismicity hosted by both north and south dipping normal faults (Figure 1a,b) [Moretti et al., 2003; Zygouri et al., 2008]. According to Global Positioning System (GPS) data, the Corinth rift is extending $\sim 10-15 \mathrm{~mm} / \mathrm{yr}$ in its central part and $6.4 \pm 1.0 \mathrm{~mm} / \mathrm{yr}$ for the eastern part between 22.5-23.1 ${ }^{\circ}$ E [e.g., Clarke et al., 1997; Briole et al., 2000; Reilinger et al., 2010].

The latest surface rupturing earthquakes in the eastern Corinth rift occurred during the 1981 Alkyonides earthquake sequence (Figure 1). This earthquake sequence comprised three earthquakes on February 24, 25 and March 4, 1981 with $\mathrm{M}=6.7,6.4$ and 6.3, respectively [Jackson et al., 1982; Hubert et al., 1996]. All of these earthquakes were normal faulting events with extension in N-S direction that fits the orientation of mapped fault traces and striations (Figure 1) [Morewood and Roberts, 2001]. While the first two shocks ruptured the northward-dipping Pisia and Skinos faults, the third ruptured the southward-dipping Kaparelli fault farther to the NE (Figure 1c) [Hubert et al., 1996; Morewood and Roberts, 2001]. The detailed 1981 slip distribution was observed directly after the earthquakes and revealed up to $150 \mathrm{~cm}$ of displacement on the Pisia fault plane, and up to $100 \mathrm{~cm}$ of displacement on the Skinos and Kaparelli fault planes (Figure 2a) [Jackson et al., 1982; Mariolakos et al., 1982; Bornovas et al., 1984].

In addition to the 1981 earthquake events, two major earthquakes on April 221928 $\left(\mathrm{M}_{\mathrm{b}} 6.3\right)$ and February 211858 (M 6.5) caused strong shaking in the eastern Corinth rift [Drakopoulos et al., 1978; Ambraseys and Jackson, 1990; Papazachos and Papaioannou, 1997; Koukouvelas et al., 2017]. The area of shaking during both events was located south and southwest of the Pisia fault in the wider area around Corinth. The reported shaking area, together with the observation of fallen blocks from the southern Gerania Mountains during the 1928 earthquake, suggests that a south-dipping fault hosted this rupture [Drakopoulos et al., 1978]. During the 1858 earthquake, enormous fallen blocks from Acrokorinthos and Oneia Mountains suggest a hypocenter on the Kenchreai fault [Koukouvelas et al., 2017]. No indicators for historic earthquakes that ruptured the Pisia and Skinos faults are reported, except for the 1981 events. However, it cannot rule out that additional historical events have occurred on these faults because the seismic catalogues of Greece are only considered complete for events of M 5.5-6.5 since 1911 [Papanikolaou et al., 2015b].

The Pisia and Skinos faults represent the western and central segments of the South Alkyonides Fault System (SAFS), which continues farther eastwards with the offshore East Alkyonides fault and the predominantly onshore Psatha fault (Figures 1c) [Roberts, 1996a]. Based on the recent earthquakes in 1981 and on slip direction analyses, it is assumed that earthquakes rupture parts of the SAFS and not the whole system at once; [Roberts, 1996; Deligiannakis et al., 2018]. Available slip rate determinations are restricted to the central and eastern half of the SAFS, which cover significantly different timescales from $1.5 \mathrm{kyr}$ to $\sim 2.2 \mathrm{Myr}$, with calculated slip rates of 0.2-2.75 mm/yr [Armijo et al., 1996; Collier et al., 
1998; Leeder et al., 2002, 2008; Sakellariou et al., 2007]. Further research is required to determine a clear image of the time-dependent slip distribution along the SAFS. So far, the analysis of paleoearthquakes is limited to paleoseismic trenching at the Skinos fault suggesting an earthquake recurrence of 330 years during the past $1.5 \mathrm{kyr}$ [Collier et al., 1998].

Although the 25-km-long Pisia fault has been widely investigated, slip rates and ages of paleoearthquakes for this fault remain unknown [e.g., Bastesen et al., 2009; Roberts and Stewart, 1994]. The Pisia fault is best exposed in its central section (8-17 km from its western tip), where it runs through Triassic to lower Jurassic carbonates of the Boeotian zone [IGME, 1984]. The central section is characterized by a pronounced geomorphologic relief of up to $600 \mathrm{~m}$, including some degraded triangular facets (Figure 2b,c). The distribution of the surface offsets during the 1981 earthquakes appears to correlate with the escarpment height (Figure 2a). The largest observed coseismic displacement of 1981 was $150 \mathrm{~cm}$, which occurred $15 \mathrm{~km}$ from the fault's western tip in a very steep area of exposed Mesozoic limestone (Figure 2a,b,c) [Jackson et al., 1982]. In this area colluvial sediments cover the fault trace. The high erosion and sedimentation rate is continuous along the eastern part of the Pisia fault where $20 \mathrm{~cm}$ of coseismic displacement was found in upper Jurassic ophiolites [Jackson et al., 1982; Bornovas et al., 1984; own findings]. In the western third of the Pisia fault, coseismic displacements of 2-40 cm was generated along a fault scarp formed in cohesively weak lithologies, including alluvial sediments, flysch and volcanic-sedimentary mixed units [e.g., Bornovas et al., 1984; Maroukian et al., 2008].

The center of the fault is located around the village of Pisia, where coseismic displacements of $\sim 60-100 \mathrm{~cm}$ were reported (Figure $2 \mathrm{a}$ ). An excavated $\sim 50$-m-high limestone fault scarp in Pisia shows the offset of the 1981 earthquake by its change in lichen colonization. In the section 1 to $3 \mathrm{~km}$ east of Pisia, the fault exhibits a continuous fault scarp along a forested $\sim 36^{\circ}$ slope of limestone lithologies (Figure 2b,c). A well-preserved limestone free-face of 3-9 m height occurs frequently. Partly, surface ruptures displaced the colluvium in the hanging wall leading to soft-rock fault scarps. These sections are related to a significant decrease in the height of the free-face. At a site where surface deformation is limited to the main fault trace, the study of Wiatr et al. [2015] detected stripes of different ruggedness parallel to the scarp base (site W15 in Figure 2b). Stripe identification imply a periodical exhumation of the fault plane due to earthquakes with coseismic displacements between 30$60 \mathrm{~cm}$. Five similar sized stripe heights emphasize that several earthquakes of M 6.4-6.7 occurred during the past few thousand years. Structural measurements on the fault plane within $2 \mathrm{~km}$ of the site of Wiatr et al. [2015] revealed a fault dip of $60^{\circ}$ towards $350^{\circ}$, with significant corrugation deviating $\pm 40^{\circ}$ from the fault strike (Figure $2 \mathrm{~d}$ ). Striations plunge on average $57^{\circ}$ towards $350^{\circ}$, confirming the pure normal faulting character (Figure 2d).

\section{Site selection}

We mapped the trace of the Pisia fault to identify suitable study sites and to search for indicators of past offsets. Ideally, the fault plane should have only been exhumed by earthquakes and remained exposed since each respective exhumation. Suitable sites should not have been affected by denudation processes (e.g., channel incision, landsliding events and/or fault scarp degradation), depositional processes (e.g., alluvial or scree deposits) or anthropogenic processes (e.g., agriculture, road construction, quarries) [Schlagenhauf et al., 2010, Bubeck et al., 2015]. For uncertainty minimization, we favored locations with high amounts of coseismic slip and minor strike-slip components, which predestinates the fault center. We excluded locations near segment boundaries and breached relay bands since their associated slip rates are not representative of the main fault [Faure Walker et al., 2009]. 
For instance, site P6 is located away from rivers and gullies, so that erosion and scarp exhumation by incision can be excluded (Figure 2b). Furthermore, at this site the hanging wall surface has been well preserved without significant erosion or deposition. A ground penetrated radar (GPR) grid covering the first $30 \mathrm{~m}$ of the hanging wall shows slope-parallel reflectors for the uppermost $\sim 5 \mathrm{~m}$ of subsurface, which rules out landsliding events. No indicators of anthropogenic activity occur since the site is far away from the village, roads and even paths (Figure $2 \mathrm{~b}$ ). We observed a deviation of $11^{\circ}$ between the striation azimuth and the fault dip direction (i.e., a rake of $79^{\circ}$ ) within $\pm 5 \mathrm{~m}$ of site P6 (Figure 2e). This is related to the local corrugation of the fault plane, since the direction of the fault dip and striation show dip-slip movement when averaged over a larger area (Figure 2d). A 13 m high fault scarp is exposed for $25 \mathrm{~m}$ along strike, whose geometry is revealed from topographic profiles. The profiles show all the typical features of bedrock fault scarps, with the hanging wall being the shallowest slope, followed by a steep free-face, a shallower degraded upper scarp and a footwall that is slightly steeper than the hanging wall (Figure 3) [compare to Stewart and Hancock 1990b, 1991; Papanikolaou et al., 2005; Mason et al., 2016; Cowie et al., 2017].

\section{Weathering analyses and surface property changes}

Previous globally distributed studies identified several surface properties that indicate distinct periods of fault plane exhumation and these surface properties are summarized in figure 4. For instance, horizontal stripes of different colors have been described on recently exposed fault planes by Lyon-Caen et al. [1988], Benedetti et al. [2003], Giaccio et al. [2003], Caputo et al. [2004], Wiatr et al. [2015], Mildon et al. [2016], and Pizzi et al. [2017]. These different colors are probably related to a combination weathering crusts and/or lichen colonization [e.g., Török, 2003]. Statistical investigations of the lichen colonization using their different size, amount of surface coverage and amount of species types can reveal relative exposure durations in the range of a few to hundreds of years [e.g., Bull et al., 1994, Bradwell, 2009; Wiatr et al., 2015] (Figure 4). For longer time scales, different grades of karstification have been related to weathering and exposure. For instance, the studies of Wallace [1984] and Giaccio et al. [2003] described horizontal bands of high surface roughness on fault planes (pitted bands), which they interpret as biokarstic weathering features. These features probably developed in the contact zone of the fault plane with the vegetated area (Figure 4). The pitting took place until the section was raised above the biogenic weathering influence zone. Subsequently, the next stripe of pitting could be formed at the fresh part of the fault plane. Another product of limestone weathering on fault planes is the development of solution flutes (karren) due to water runlets is [e.g., Mottershead and Lucas, 2001]. Water runlets cease when reaching the soil level, so that developed solution flutes terminate at the scarp base (Figure 4). After an exhumation of the fault plane, the location of water runlets can shift or they continue in the old runlets resulting in abrupt changes of solution flute depth and/or width at the ancient scarp base (Figure 4).

\subsection{Methods}

Along a $1.6 \mathrm{~km}$ section of the central Pisia fault, we used visual observations on the exhumed free-face to detect color changes, lichen colonization changes, and different karstification features. Scale bar measurements were used to determine the height of the stripes above the local scarp base. These measurements were limited to locations where markers are well preserved. At larger sites, structure-from-motion photogrammetry using Agisoft PhotoScan ${ }^{\circledR}$ helped to keep the undistorted overview of the fault plane. Uncertainties in the horizon height are only given for sites where multiple measurements of different features were possible. Here, a maximum - minimum measurement range is considered. 
At the best-preserved site (site P6), a terrestrial laser scanning (TLS) survey was performed to study changes of surface properties independently from the visual mapping. The scan was taken after excavating $2 \mathrm{~m}$ of soil at the scarp base to compare the surface properties between the weathered and unweathered fault plane. The Faro Focus 3D laser system calculated the distance and stored the backscatter signal intensity of each scanned point. Subsequently, the data was reduced to a raster cell size of $5 \times 5 \mathrm{~mm}$.

The spatial data images the fault plane in $3 \mathrm{D}$ and high-resolution and the surface morphology was analyzed using the terrain ruggedness index (TRI) after Riley et al. [1999]. The backscatter signal intensity provides information on a mixed range of surface properties. These include moisture, roughness, the range between sensor and target, and the angle of incidence [Wiatr et al., 2015; Schneiderwind et al., 2016]. The backscatter intensities were treated by hierarchical unsupervised clustering, meaning that all data points are assigned to existing cluster centers during each iteration, and that the new means are then recalculated for every class (ISO, iterative self-organizing clustering). Different combinations of backscatter ISO clusters were analyzed to highlight surface property changes on the fault plane.

Furthermore, two vertical profile lines were analyzed for their surface property changes using (i) peaks and breakpoints, (ii) the variability pattern of the data, and (iii) the recognizability of patterns across most of the profiles. Further details of the TLS methodology are given in the supplementary material (text $\mathrm{S} 1$ ).

\subsection{Results of the visual mapping}

At most bedrock fault scarp locations a $\sim 1.1 \mathrm{~m}$ high horizontal stripe of different color is visible at the scarp base (Figures 5, S1, S2a). This stripe is either lighter or darker than the upper part of the free-face. Its measured height variability is \pm 0.05 to $\pm 0.20 \mathrm{~m}$. On higher parts of the fault plane, color changes are not significant with the exception of site P4 (Figure $5 \mathrm{a}$ ). Only $0-5 \%$ of the lower stripe is colonized by lichen, which is in marked contrast to the $>95 \%$ of lichen cover on the fault plane above this stripe (Figure S3a,c,d). With increasing height, the number and size of different lichen species increases; for instance, various species reach $15 \mathrm{~cm}$ in diameter at $>4 \mathrm{~m}$ scarp height (Figure S3). However, due to their arbitrary distributed growth locations it is not possible to narrow down precise stripe boundaries except for the one at $\sim 1.1 \mathrm{~m}$ height.

Horizontally pitted bands were found at several sites and at a range of free-face heights (Figure $5 \mathrm{c}, \mathrm{d}, \mathrm{e}$ ). The band at a height of $\sim 2 \mathrm{~m}$ is particularly well developed at site P6, where it is $\sim 10 \mathrm{~cm}$ wide. Another clearly pitted band occurs at a height of 3.6-3.9 m (horizon EQ4, Figure 5d). In addition to pitting, a progressive evolution of solution flutes was mapped at several locations. For instance, at $4.15 \mathrm{~m}$ above the scarp base at site P6, at least three flutes terminate and one flute decreases significantly in width and depth (Figures 5d, S2f).

At the westernmost part of the mapped fault trace (1.6 km west of Pisia village), the absence of a fault scarp and of coseismic 1981 surface ruptures indicate the end of a fault segment [Jackson et al., 1982] (Figures 2a, 6a). Towards the east, the free-face heights increase together with the height of the lowest horizontal stripe. The stripe height increases from $0.3 \mathrm{~m}$ to $1.1 \pm 0.2 \mathrm{~m}$ within $300 \mathrm{~m}$ and afterwards this height is continuous for at least $1.3 \mathrm{~km}$ (Figure 6b). The measurements were limited to stable locations without parallel deformation features like the soft rock fault scarp east of site P7. Reliable indicators for upper horizons are limited to five locations since the higher part of the fault plane is either poorly preserved or inaccessible due to vegetation cover (trees, bushes, moss). The height of the second horizon (EQ2) at these locations indicates the same trend of increasing eastward until reaching $\sim 2.1 \mathrm{~m}$ height at site P6. At three locations a third horizon was identified up to $3.0 \mathrm{~m}$ 
height (Figure 6b). At the best-preserved location (site P6) a pitted band and solution flute terminations indicate further horizons at heights of $\sim 3.60 \mathrm{~m}, \sim 4.15 \mathrm{~m}, \sim 5.15 \mathrm{~m}$, and possibly also at $\sim 4.65 \mathrm{~m}$ (Figures 5c,d, S1, S2).

\subsection{Results of terrestrial laser scanning (TLS)}

At site P6, the analyses of the TLS data reveal high resolution surface properties on the fault plane up to a height of $3.7 \mathrm{~m}$ (Figures 7, S4). Above this height, the data resolution is too low for an independent and precise analysis due to the dragging footprint of data points. While no clear spatial variation can be detected on the map of the TRI data (Figure 7a), the backscattered signal indicates variable and lower intensities from $-1.9 \mathrm{~m}$ to $+1.1 \mathrm{~m}$ height compared to $>1.1 \mathrm{~m}$ height (Figure $7 \mathrm{~b}$ ). The classified backscatter signal reveals a $\sim 25 \mathrm{~cm}$ high stripe above the scarp base (dominated by cluster \#3, Figure 7c) and an abrupt change of the cluster combinations at $\sim 1.1 \mathrm{~m}$ height. Furthermore, the map of the classified backscatter signal is evidence for surface property changes bounded at $\sim 2.03 \mathrm{~m}$ height and possibly at $\sim 2.85 \mathrm{~m}$ height (Figure 7c).

The TLS data of two sample ladders (yellow boxes from -1.9 to $+3.7 \mathrm{~m}$ in figure $7 \mathrm{a}-\mathrm{c}$ ) were analyzed and shown as the red and blue profiles in figure $7 \mathrm{~d}-\mathrm{g}$. Both profiles show the same trend with an overall identical roughness and an increasing backscattered signal from 0 $3.7 \mathrm{~m}$. They do not correlate in some peaks, particularly in the scarp section between 0-1.1 m. These peaks can be related to local pores of karstification or shear fractures and hence they are not suitable to indicate features related to the exposure (Figure $5 \mathrm{c}, 7 \mathrm{~d}, \mathrm{e}$ ).

Above $1.1 \mathrm{~m}$ scarp height, the textural TLS data has a constant trend with the exception of some discrete locations of higher micro-roughness $(>4 \mathrm{~mm})$ and peaks into respective higher TRI classes (Figure 7d, e). Most of these peaks are not related to observable pre-exposure fault plane features and they likely indicate surface roughness changes due to fault plane exposure (e.g., micro-pitting). The changes towards roughness peaks occur at heights of $\sim 2.0 \mathrm{~m}, \sim 2.8 \mathrm{~m}, \sim 3.1 \mathrm{~m}$, and $\sim 3.6 \mathrm{~m}$ (Figure $7 \mathrm{~d}, \mathrm{e}$ ). The height of the changes and peaks in the right and left profiles agree within $\pm 5 \mathrm{~cm}$. In addition, with the height of the sample boxes of $5 \mathrm{~cm}$, we are confident that the locations of changing roughness are accurate to within $\pm 10 \mathrm{~cm}$.

The profiles of the TLS backscatter data (Figure $7 \mathrm{f}, \mathrm{g}$ ) indicate a strong signal rise from $0-1.1 \mathrm{~m}$ scarp height ( $~ 800$ to $\sim 1500$, clusters 3 to 8 ), followed by a uniform distribution of clusters 6-8 from 1.1-2.0 m height. The subsequent higher section between 2.0 and $2.8 \mathrm{~m}$ is characterized by a wider variety of classes with influences from clusters 6 to 9 (Figure 7c, g). While the section between 2.8 and $3.1 \mathrm{~m}$ also shows a certain influence from lower backscatter intensities, the uppermost section (3.1-3.6 $\mathrm{m}$ ) is characterized by an almost constant backscatter value of $\sim 2000$ with very low standard deviations corresponding to cluster 9 (Figure 7f, g). Even the trenched parts are allocated to a certain combination of backscatter ISO clusters, which refer to distinct spectral characteristics. The profile appears highly variable due to the appearance of clusters 1,2 and 10 , which is a significantly different signature compared to the other sections (Figure 7c, g).

In summary, the TLS data analyses at site P6 suggest distinct surface properties changes at $1.1 \mathrm{~m}, 2.0 \mathrm{~m}, 2.8 \mathrm{~m}, 3.6 \mathrm{~m}$, and possibly also at $3.1 \mathrm{~m}$ (all with $\sim 0.1 \mathrm{~m}$ uncertainty) (Figure 7).

\subsection{Interpretation of the horizon formation}

The visual field observations and the TLS measurements at site P6 reveal identical horizon heights (Figure 7h). For instance, the increase in roughness observed in the profiles 
of textural TLS data agrees with the mapped occurrence of micro-pitting. The good correlation of the results from the different methods underlines the significance of the detected features as progressive exhumation event indicators.

Since we only used sites where erosion of the soil cover at the scarp base can be largely ruled out, the major part of the fault plane exhumation can be related to coseismic displacement during earthquake ruptures. The height of the lowermost horizon EQ1 agrees with the amount of reported coseismic displacement during the 1981 earthquake series [Jackson et al., 1982; Roberts and Ganas, 2000; Wiatr et al., 2015] (Figure 6a). The observed horizon heights at site P6 appear to be representative for coseismic offsets along the central part of the Pisia fault (Figure 6b). Since this site shows the best record of earthquake horizons, it was sampled for cosmogenic ${ }^{36} \mathrm{Cl}$ exposure dating.

\section{$5{ }^{36} \mathrm{Cl}$ sampling and chemical analyses}

The ${ }^{36} \mathrm{Cl}$ cosmic ray exposure dating was used to measure the timing of the progressive exhumation events of the Pisia fault plane. The technique is based on the accumulation of in situ-produced ${ }^{36} \mathrm{Cl}$ on the fault plane at a constant rate after exhumation to the surface. This method has been highly improved during the past years and has been successfully used to date earthquakes and calculate slip rates for several limestone fault scarps [e.g., Zreda and Noller, 1998; Benedetti et al., 2002, 2003; Schlagenhauf et al., 2010, 2011; Benedetti et al., 2013; Tesson et al., 2016; Cowie et al., 2017].

The fault plane at the most suitable site P6 of the central Pisia fault was sampled for ${ }^{36} \mathrm{Cl}$ analysis. The samples were taken in the best-preserved line on the fault plane at a bearing of $351^{\circ}$ (Figure $5 \mathrm{~d}$ ), which deviates from the average orientation of the striation by only $4^{\circ}$. Additionally, the buried portion of the fault plane $(-1.95$ to $0 \mathrm{~m})$ was sampled at a bearing of $347^{\circ}$ parallel to local striations. These subsurface samples are required to allow a precise analysis of the ${ }^{36} \mathrm{Cl}$ pre-exposure concentrations. At the boundary between the surface and subsurface, a sampling step of $30 \mathrm{~cm}$ was required to avoid an outcropping bow-shaped fracture (Figure 5c).

The sample ladders for ${ }^{36} \mathrm{Cl}$ analyses were cut with an angle grinder and sample blocks were removed using a hammer and chisel. The samples were taken in a continuous column unless surface preservation was poor, in which case gaps were left $(\max .45 \mathrm{~cm})$. The samples were prepared at the Institute of Geology and Mineralogy of the University of Cologne. Weathered parts, reprecipitated minerals and pore surroundings were carefully removed with a rotary tool before crushing and sieving. The following chemical treatment and the measurement at the CologneAMS facility was performed as described in Rixhon et al. [2018] and Gromig et al. [2018]. Unused sample material was archived. Resulting ${ }^{36} \mathrm{Cl} /{ }^{35} \mathrm{Cl}$, ${ }^{36} \mathrm{Cl} /{ }^{37} \mathrm{Cl}$ and ${ }^{35} \mathrm{Cl} /{ }^{37} \mathrm{Cl}$ ratios were used to calculate the concentrations of ${ }^{36} \mathrm{Cl}$ and natural chlorine $\left(\mathrm{Cl}_{\text {nat }}\right)$. Their reliability is confirmed by the simultaneous preparation of CoCal-N ${ }^{36} \mathrm{Cl}$ standard material [Mechernich et al., 2017] and blanks in the respective batches. The blank subtractions were $1.4-13.7 \%$ (Table S1). The calculated ${ }^{36} \mathrm{Cl}$ concentrations of the 38 analyzed samples range from $\sim 1 \times 10^{5}$ at $/ \mathrm{g}$ rock at $1.9 \mathrm{~m}$ below the scarp base to $\sim 5 \times 10^{5}$ at $/ \mathrm{g}$ rock at a height of $8.4 \mathrm{~m}$. In general, the concentrations are continuously increasing with fault scarp height (Figure 8). The natural chlorine concentrations are very low, from 6-17 $\mu \mathrm{g} / \mathrm{g}$ with an average of $9.5 \mu \mathrm{g} / \mathrm{g}$ (Table S1). Five replicate samples were prepared and measured on Cologne AMS; two additional replicates were prepared at the University of Cologne and measured at the French national AMS facility Accélérateur pour les Sciences de la Terre, Environnement, Risques (ASTER, France) (white-green data points in Figure 8; Table S1).

An aliquot of each dissolved sample was analyzed by in-house ICP-OES at the 
University of Cologne to determine the concentrations of the principal ${ }^{36} \mathrm{Cl}$ target elements, $\mathrm{Ca}, \mathrm{K}, \mathrm{Ti}$ and $\mathrm{Fe}$. To characterize the thermal and epithermal neutron flux and thus constrain production of ${ }^{36} \mathrm{Cl}$ on ${ }^{35} \mathrm{Cl}$, we selected bulk non-treated material; five from the free-face and two colluvial samples. Trace element analysis was undertaken on these samples at Actlabs (Canada) and their respective average values were used for the ${ }^{36} \mathrm{Cl}$ production estimates (Table S2). While the bedrock is a limestone with $55.6 \pm 0.6 \% \mathrm{CaO} ; 0.9 \pm 0.4 \% \mathrm{MgO}$, and $0.06 \pm 0.01 \% \mathrm{SiO}_{2}$, the soil comprises $35.6 \pm 1.8 \% \mathrm{CaO}, 2.2 \pm 0.6 \% \mathrm{MgO}$ and $22.6 \pm 3.9 \%$ $\mathrm{SiO}_{2}$ (Table S2). Uncertainties for the Ca measurements on the ICP-OES range between 1.5 and $2.5 \%$. The nominal Ca concentrations range from $37.9 \%$ to $40.3 \%$, indicating local variabilities (Table $\mathrm{S} 2$ ) with a minor impact on the ${ }^{36} \mathrm{Cl}$ production rate.

\section{$6{ }^{36} \mathrm{Cl}$ data modeling}

To determine earthquake ages from the ${ }^{36} \mathrm{Cl}$ concentrations we used the Matlab ${ }^{\circledR}$ code of Schlagenhauf et al. [2010] that models synthetic ${ }^{36} \mathrm{Cl}$ concentrations while accounting for all influencing factors, i.e., the time-dependent variability of the fault scarp geometry, the chemical composition and the respective amount and timing of progressive exhumation steps. All input parameters are described in detail in the supplementary material (Text S2.1, Tables S1-S3) and the major ones are listed in Figure 8a.

Two different methods were applied to evaluate the most likely exhumation history. First, we used an iterative and manual approach by successively adapting the event ages along the height of the fault scarp from oldest to youngest (see text S2.2). The statistically more likely scenarios were revealed by the lowest weighted-root-mean-square (RMSw), Chisquare $\left(\chi^{2}\right)$, and Akaike Information Criterion (AICc) values [Schlagenhauf et al., 2010]. Secondly, we applied the Bayesian Markov Change Monte Carlo (MCMC) modeling approach presented by Cowie et al. [2017], that implements the Matlab® code of Schlagenhauf et al. [2010] and obtains the best-fitting model automatically and objectively (for details see text S2.2 and supplementary information of Cowie et al., 2017).

\subsection{Manual iteration}

The most likely exposure history of the manual iteration approach results in exhumation ages of 2.0 $0^{+0.5}{ }_{-0.6} \mathrm{kyr}(\mathrm{EQ} 2), 3.1^{+1.4}{ }_{-0.6} \mathrm{kyr}$ (EQ3), 4.4 ${ }_{-0.4}^{+0.6} / 4.3^{+0.7}{ }_{-0.3}$ and $4.5^{+0.5}$. $0.5 \mathrm{kyr}(\mathrm{EQ} 4 / 4 \mathrm{a}, \mathrm{b}), 6.0^{+0.3}-1.0 \mathrm{kyr}(\mathrm{EQ} 5)$, and $7.1^{+0.6}{ }_{-0.9} / 6.8^{+0.4}{ }_{-0.7}$ and $7.3^{+0.5}-0.7 \mathrm{kyr}(\mathrm{EQ6} / 6 \mathrm{a}, \mathrm{b})$ (Figure 8a). The statistical control indicates $\mathrm{RMSw}=5.32, \mathrm{AICc}=1844$, and $\chi^{2}=14.2$. To show the influence of different earthquake recurrence intervals on the modeled ${ }^{36} \mathrm{Cl}$ concentration, we highlight an example with a longer time interval between EQ2 and EQ3 (2.4 kyr in the pink scenario in Figure $8 \mathrm{~b}$ ), which appears to be likely because of the clear exponential decrease of the ${ }^{36} \mathrm{Cl}$ concentrations. The best data fit for a longer time interval between EQ2 and EQ3 results in shorter recurrence periods for the earthquakes before and after. Although the exponential character of the ${ }^{36} \mathrm{Cl}$ curve is clearly modeled in the pink scenario, the data points between 1 and $2 \mathrm{~m}$ scarp height show a poorer fit compared to the best fitting scenario shown in blue (Figure 8b).

To estimate the overall robustness of the earthquake ages, Figure $8 \mathrm{c}$ indicates the range of modeled ${ }^{36} \mathrm{Cl}$ concentrations for earthquake scenarios with $\mathrm{RMSw}<7.0$, AICc $<1870$, and $\chi^{2}<25$. These models correspond to ages ranging within $\sim \pm 0.7 \mathrm{kyr}(1 \sigma$ uncertainties) (Figure 8c).

The modeling of the exhumation history of the upper part of the free-face (5.15$8.45 \mathrm{~m}$ ) suggests event ages of $8.2 \mathrm{kyr}, 8.3 \mathrm{kyr}, 8.5 \mathrm{kyr}, 9.1 \mathrm{kyr}$ and $10.2 \mathrm{kyr}$ in the most likely model (Figure 8a). This is based on an assumed coseismic slip amount of $66 \mathrm{~cm}$, which 
is the average value of the detected event horizons. These ages have higher uncertainties compared to the lower part of the fault scarp due to (i) the unknown location of the earthquake horizons, (ii) a significant impact of the estimated pre-exposure component (inheritance), and (iii) the apparent slip history of the degraded scarp. The calculated age range variability of up to ${ }^{+1.8} / .1 .9 \mathrm{kyr}$ includes all likely models $(\mathrm{RMSw}<7.0, \mathrm{AiCc}<1870$ and $\chi^{2}<25$ ) for the range of tested pre-exposure durations and apparent slip rates of the degraded fault scarp (Figures 8c, 9a).

The slip evolution resulting from the manual iterative modeling is visualized in Figure 9a. It implies that the $8.45 \mathrm{~m}$ high free-face was exhumed at an average rate of 0.6$0.9 \mathrm{~mm} / \mathrm{yr}$ within the last $10.2^{+1.8}-1.9 \mathrm{kyr}$ (orange line in Figure 9a). However, this rate does not fit the data well, suggesting some slip rate variability. The data suggests that it is reasonable to use the paleoearthquake horizon EQ6b (5.15 m height) as slip rate interval separation. This results in a slip rate of $0.5-0.6 \mathrm{~mm} / \mathrm{yr}$ for the last $7.3^{+0.5}-0.7 \mathrm{kyr}$, and a preceding accelerated tectonic phase that exhumed the upper part of the free-face (5.15$8.45 \mathrm{~m}$ ) at a rate of $0.8-2.3 \mathrm{~mm} / \mathrm{yr}$ during the early Holocene.

\subsection{Bayesian MCMC modeling}

The MCMC modeling code of Cowie et al. [2017] allows a Bayesian analysis of the Matlab ${ }^{\circledR}$ code of Schlagenhauf et al. [2010]. We adapted the published MCMC code to allow the input of variable exhumation steps and hence the use of the same input parameters as used in the manual iterative approach (see text S2.2). After a representative amount of 101,000 iterations, the best-fitting scenario revealed an RMSw value of 5.56 (Figure 9b, for criteria see text S2.2). The range of the 100 most likely scenarios indicate slip rate variations with $0.50-0.65 \mathrm{~mm} / \mathrm{yr}$ for $1.10-5.15 \mathrm{~m}$ scarp height, $0.66-2.0 \mathrm{~mm} / \mathrm{yr}$ for $5.15-8.45 \mathrm{~m}$ scarp height, and an apparent rate of $0.37-0.51 \mathrm{~mm} / \mathrm{yr}$ for the degraded fault scarp (8.45-14.6 m height) (Figure 9b). Please note that the implication of the slip rate of the degraded part of the fault scarp is highly related to erosional and resulting sedimentary components. It is therefore not possible to only obtain information on the tectonic rate. Hence, the interpretation of the seismic history is limited to the free-face, where the slip rate during the early Holocene appears to have been almost twice as high as during the mid and late Holocene.

\section{Discussion}

Bedrock fault scarp analyses have been increasingly used in recent times for paleoseismologic interpretations because new dating techniques have allowed the fault plane to be investigated directly. As stated by Bubeck et al. [2015] and Cowie et al. [2017], a careful site selection using geomorphologic and structural mapping is crucial to understand the processes responsible for bedrock exhumation. We used only sites where erosion of soil cover can be largely ruled out as a control of scarp exhumation. Furthermore, the slope erosion in the study area is generally low, since even at sites with an uneven scarp base the lowest horizontal stripe has a constant height (e.g., site P7, Figure 5b).

\subsection{Earthquake horizons}

In addition to the selection of a suitable site, the determination of event horizons is the controlling factor for interpreting the earthquake history. The largest uncertainty is the possibility of overseeing earthquakes, which occurs particularly if the earthquakes have a low recurrence period. Combining different methods to allow the most complete detection of earthquake horizons should always be undertaken.

Different fault plane appearance based on color contrast and lichen colonization are 
the best indicators of the 1981 earthquake horizon. At sites P4 and P19 the distince fault plane appearance could also be used to visualize the earthquake horizons for the penultimate earthquake (Figure 5a, e). This suggests that their use as horizon detection criterion has a temporal resolution of $\sim 2 \mathrm{kyr}$ in this climatic environment.

Since lichen produce a smooth calcium oxalate patina [Chen et al., 2000], significant colonization can have effects on the roughness of the fault plane (Figure S3c, d). For instance, TLS data at site P6 shows that the fault plane has a constant roughness at the completely colonized scarp heights of 1.1 to $5.4 \mathrm{~m}$. Simultaneously, the fault plane is slightly smoother on the uncolonized parts (-1.9 to $1.1 \mathrm{~m}$; Figure $7 \mathrm{a}, \mathrm{d}, \mathrm{e})$. Hence, the expectation of an increasing roughness with exposure duration needs to be applied carefully [e.g., Wallace, 1984; Stewart, 1996; Giaccio et al., 2003; Brodsky et al., 2011; He et al., 2013].

The use of limestone-weathering features like solution flutes and pitted areas suggests a millennial time frame for horizon detection. Their formation appears to require more than 33 years according to the overall lack of weathering features on the stripe exhumed during the 1981 earthquakes. Most earthquake recurrence intervals were modeled around $1 \pm 0.5 \mathrm{kyr}$ (Figure 8c), which appears to be sufficiently long to allow the development weathering features. This is in agreement with the findings of Mottershead and Lucas [2001]. As weathering is an anisotropic process depending on local factors of water runoff and biotic activity, it is unlikely to find the features at each site and at each time step. For example, the development of horizontal pitted bands (EQ2, EQ4 at site P6) required a several decimeter thick biogenic influence area at the base of the fault scarp, which is not occurring nowadays. This might be the reason why there is no pitted band directly above the 1981 earthquake horizon, even though this horizon defined the scarp base for $2.0^{+0.5}{ }_{-0.6} \mathrm{kyr}$. These variabilities emphasize the need for detailed mapping along the fault to avoid overseeing horizon indicators.

In the middle of the free-face at site P6 (4.15-5.5 m, EQ5, EQ6a, EQ6b; Figure 5d), the short solution flutes of $\sim 50 \mathrm{~cm}$ length might suggest a new flute development after each earthquake. This might be related to reorganized pathways of water runoff in the porous and partly fractured limestone. While four and six of these flutes are interpreted to mark the horizons of EQ5 and EQ6b, the horizon of EQ6a at $4.65 \mathrm{~m}$ height was identified based on only two of these short flutes. It is likely that they indicate an earthquake horizon; however, the possibility of a coincident termination at the same height should not be excluded.

The analysis of the TLS data revealed a possible additional event horizon EQ4a at $3.1 \mathrm{~m}$ scarp height. It is shown in the textural data of both profiles with similar roughness changes to those observed at horizons EQ3 and EQ4 (Figure 7d, e). This horizon would imply two displacement events of $\sim 25$ (EQ4a) and $\sim 50 \mathrm{~cm}$ (EQ4b), instead of $\sim 75 \mathrm{~cm}$ in one event (EQ4).The methodological uncertainties in the height of the detected horizon are in the range of $\pm 10 \mathrm{~cm}$ for the TLS data and \pm 5 to $\pm 20 \mathrm{~cm}$ for the visual observations at the respective sites (Figures 5, 7). These uncertainties account also for the horizon height variation along fault strike (Figure 6b), which implies a remarkably low scatter compared to the highly variable coseismic displacements observed after the 2016 Italy earthquake sequence [Villani et al., 2017].

Based on the obtained horizon heights, the most likely average coseismic offsets along the central Pisia fault were: $110 \mathrm{~cm}$ (EQ1 in 1981); $95 \mathrm{~cm}$ (EQ2); $80 \mathrm{~cm}$ (EQ3); 75, or $25+50 \mathrm{~cm}(\mathrm{EQ} 4 / 4 \mathrm{a}, \mathrm{b}) ; 55 \mathrm{~cm}(\mathrm{EQ} 5)$; and 100, or $50+50 \mathrm{~cm}(\mathrm{EQ} 6 / 6 \mathrm{a}, \mathrm{b})$. Towards the western segment boundary these values appear to decrease continuously for each paleoearthquake. This is confirmed by our visual observations and the TLS study of Wiatr et al. [2015] (Figure 6b), who determined offsets of $60 \mathrm{~cm}$ (EQ1 in 1981), $50 \mathrm{~cm}$ (EQ2), $50 \mathrm{~cm}$ (EQ3), $30 \mathrm{~cm}$ (EQ4) and $>30 \mathrm{~cm}$ (EQ5) for a location $180 \mathrm{~m}$ to the west of site $\mathrm{P} 6$ and $150 \mathrm{~m}$ 
away from the segment termination. The observation of such quickly decreasing offsets emphasizes the need for a carefully chosen study location to allow realistic paleomagnitude and slip rate calculations.

So far, most studies used a regular distribution of ${ }^{36} \mathrm{Cl}$ samples to statistically determine the location of earthquake horizons on the fault plane using probability density functions [e.g., Schlagenhauf et al., 2010; Benedetti et al., 2013; Tesson et al., 2016]. Ten samples per meter are commonly taken, making a time and cost intensive operation. At the Pisia fault, the production rate of ${ }^{36} \mathrm{Cl}$ is rather low due to the low altitude and latitude, which lowers the sensitivity of the earthquake detection. At today's scarp base, the distribution of ${ }^{36} \mathrm{Cl}$ concentrations indicates an exponential shape (Figure 8), although it was only exposed for 33 years before the sampling. In contrast, no change in ${ }^{36} \mathrm{Cl}$ concentrations is observed around $\sim 1.1 \mathrm{~m}$ height (Figure 8), which served as the scarp base for at least 70 years preceding the 1981 earthquake according to historical earthquake reports. This suggests that the apparent pattern of ${ }^{36} \mathrm{Cl}$ concentrations along the free-face height is related to chemical differences in sample composition and the ${ }^{36} \mathrm{Cl}$ measurement uncertainties, rather than exposure duration. Hence, apparent ${ }^{36} \mathrm{Cl}$ patterns should not be mistaken as earthquake horizon indicators at the Pisia fault and other exposed sites.

The distinction of multiple smaller sized earthquake events in short time periods (temporal clustering of $<200$ years) remains problematic in all these applied methods. Therefore, the number of detected events represents the minimum number of earthquakes, while the estimated displacements are maximum bounds and thus refer to maximum earthquake magnitudes. Assuming that the slip values represent the maximum displacements in the study area, the corresponding magnitudes were $\mathrm{M}_{\mathrm{w}} 6.2-6.7$ (standard deviation \pm 0.4 ) based on the Wells and Coppersmith [1994] equation of $\mathrm{M}_{\mathrm{w}}=6.69+0.74 \times \log ($ maximum total displacement) (Figure 7h). A very similar range of magnitudes, i.e. $\mathrm{M}_{\mathrm{s}} 6.4-6.7$, is calculated using earthquake data of Aegean normal faults $\left(\mathrm{M}_{\mathrm{s}}=0.59 \times \log\right.$ (maximum vertical displacement +6 6.675) [Pavlides and Caputo, 2004]. Using the upper and lower envelope of all the Aegean data results in uncertainties of $\pm 0.3 \mathrm{M}_{\mathrm{s}}$ [Pavlides and Caputo, 2004]. These calculated magnitudes correspond to the measured moment magnitudes of the 1981 earthquakes that affected the Pisia fault with $\mathrm{M}_{\mathrm{w}} 6.7$ and $\mathrm{M}_{\mathrm{w}} 6.4$.

\subsection{Significance of ${ }^{36} \mathrm{Cl}$ modeling results}

The significance of the ${ }^{36} \mathrm{Cl}$ modeling results depends on both the used parameters and the modeling method. Changes of the input parameters concerning the ${ }^{36} \mathrm{Cl}$ production rate would be most dominant and shift the modeled earthquake ages to older or younger values, without changing the relative recurrence interval. This shift is around $10 \%$ (see text S2.2), and since the modeled $1 \sigma$ age uncertainties are mostly larger than $10 \%$, the consideration of these parameter uncertainties would result in only slightly higher overall uncertainties.

The two different modeling methods (manual and Bayesian) result in similar good fits for the ${ }^{36} \mathrm{Cl}$ data, with the best-fitting scenarios having RMSw values of 5.32 and 5.56 , respectively (Figure 9, for fitting-criteria see text S2.2). The resulting earthquake ages of the two approaches agree well within their uncertainties. For instance, the earthquake horizon EQ6b (5.15 m height) was most likely exhumed $7.3^{+0.5}{ }_{-0.7} \mathrm{kyr}$ ago based on manual modeling, and $7.2 \pm 0.9 \mathrm{kyr}$ ago based on the Bayesian modeling (Figure 9). Both models reveal a change in slip rate with 0.8-2.3 mm/yr (manual modeling) and 0.66-2.0 mm/yr (Bayesian modeling) during the early Holocene, compared to $0.5-0.6 \mathrm{~mm} / \mathrm{yr}$ (manual modeling) and $0.50-0.65 \mathrm{~mm} / \mathrm{yr}$ (Bayesian modeling) during the mid and late Holocene (Figure 9). Please note that these slip rate uncertainties do not include the uncertainties of the input parameters, which would result in an overall shift of the rates, without changing the internal slip rate 
variation. Since the manual modeling includes at least the uncertainties of the pre-exposure and apparent slip of the degraded scarp, we argue that their rates are more accurate. Tests of different pre-exposure durations highlight that the 5-9 $\mathrm{m}$ height interval indicates slightly lower slip rates for shorter pre-exposure durations, whereas the modeled ages and slip rates remain unaffected in the lower $5 \mathrm{~m}$ of the fault plane (Figure S5a-c).

The significance of the derived slip rates regarding the amount of coseismic offsets during each exhumation event was tested using the original Bayesian MCMC code. When using $100 \mathrm{~cm}$ coseismic offsets (arbitrary realistic value), the slip rates are $0.60-0.68 \mathrm{~mm} / \mathrm{yr}$ for 1-5 m scarp height and 0.64-0.97 mm/yr for 5-9 m scarp height (Figure S5b). In a 64-cm coseismic scenario, the revealed slip rates are $0.62-0.73 \mathrm{~mm} / \mathrm{yr}$ for $1.28-5.12 \mathrm{~m}$ scarp height and $0.66-0.99 \mathrm{~mm} / \mathrm{yr}$ for 5.12-8.32 $\mathrm{m}$ height (Figure S5d). Hence, both scenarios result in very similar rates, implying that the amount of coseismic offset is not the driving factor of the slip rate calculation. On the other hand, these tests suggest only slightly higher slip rates during the early Holocene, which contrasts the twice as high rate obtained from the input of the mapped coseismic offsets. This suggests that the variability of offsets is significant and that the detection of earthquake horizons results in an improved slip rate calculation.

\subsection{Slip rate implications}

The slip rate of the Pisia fault varied most likely from $0.5-0.6 \mathrm{~mm} / \mathrm{yr}$ during the mid and late Holocene to $0.8-2.3 \mathrm{~mm} / \mathrm{yr}$ during the early Holocene (Figures 9, 10). Such slip rate variations during similar timescales have been reported for several faults worldwide [Roberts et al., 2002; Friedrich et al., 2003; Koukouvelas et al., 2005; Schmidt et al., 2011; Benedetti et al., 2013; Cowie et al., 2017; D'Amato et al., 2017], highlighting the importance of detailed slip rate calculations integrating over different time intervals. The higher slip rate of the Pisia fault during the early Holocene $(7.3 \pm 0.7$ to $10.2 \pm 1.9 \mathrm{kyr})$ suggests either an increased seismicity compared to today (e.g., 5 earthquakes with $\sim 66 \mathrm{~cm}$ displacement), or the occurrence of larger slip events (e.g., 3 earthquakes with $\sim 110 \mathrm{~cm}$ displacement).

The Pisia fault overlaps with the Skinos fault, which runs 1.2-1.6 km farther north (Figure 10), and bothfaults are most likely linked at depth [Roberts, 1996b]. The combined results of three trenches across the Skinos fault show that the 1981 earthquake and four similar sized paleoearthquakes recurred every $\sim 330$ years during the past $\sim 1.5 \mathrm{kyr}$ [Collier et al., 1998] (Figure 10). Since we modeled an age range of 1.4-2.5 kyr for the penultimate event on the Pisia fault (Figure 9c), at least three of the reported paleoeaerthquakes on the Skinos fault were not accompanied with surface ruptures of the Pisia fault. This implies that at the last two earthquakes behaved differently to the 1981 earthquake events. It remains open whether each rupture of the Pisia fault is accompanied by a rupture of the Skinos fault.

The average throw rate of the Skinos fault of $0.7-2.5 \mathrm{~mm} / \mathrm{yr}$ during the past $\sim 1.5 \mathrm{kyr}$ [Collier et al., 1998] is in the same range as the Pisia fault slip rate between $7.3 \pm 0.7$ and $10.2 \pm 1.9 \mathrm{kyr}$. The decreased slip rate of the Pisia fault since $7.3 \pm 0.7 \mathrm{kyr}$ might be related to the Skinos fault releasing most stress during this time. So far, no paleoseismologic data from the Skinos fault exists beyond $1.5 \mathrm{kyr}$; it remains unknown if the fast slip rate and the low earthquake recurrence intervals are representative over tens of thousands of years. Other investigations of the SAFS are limited to indirect slip rate estimations covering time ranges of at least $12 \mathrm{kyr}$ (Figure 10, text S3). Further studies are required to test the hypothesis of a time-dependent transfer of slip between the fault segments of the SAFS.

\section{Conclusions}


The combined analysis of different surface property changes (color, lichen, karstification, roughness, backscattered laser intensity) on the free-face of the Pisia fault allows event horizon detection representing the last several thousand years. Analysis of these exposure duration features on naturally exhumed fault planes is a valuable method to restore the amount of coseismic slip during paleoearthquakes. A big advantage of this method is that the study site is perfectly preserved for future investigations.

At the central Pisia fault, the mapped coseismic offsets ranged between 25 and $110 \mathrm{~cm}$, implying recurring earthquakes with magnitudes of $M_{w} 6.2-6.7( \pm 0.4)$. The analysis of one ${ }^{36} \mathrm{Cl}$ sample every $0.3-0.8 \mathrm{~m}$ on the free-face reveals a robust age frame with modeled age uncertainties of $\sim 0.7 \mathrm{kyr}$ for each earthquake event. Further or even continuous ${ }^{36} \mathrm{Cl}$ sample analyses are not expected to improve the ages significantly, since the uncertainties of the ${ }^{36} \mathrm{Cl}$ concentrations are widely overlapping at different scarp heights. This is also expected for other bedrock fault planes at low altitudes and with intermediate to fast slip rates.

The modeling of the ${ }^{36} \mathrm{Cl}$ concentrations revealed that the last 6-8 earthquakes on the central Pisia fault occurred within the last $7.3 \pm 0.7 \mathrm{kyr}$. This is associated with a slip rate of 0.5-0.6 mm/yr. During the early Holocene the Pisia fault had a higher slip rate of 0.8$2.3 \mathrm{~mm} / \mathrm{yr}$, suggesting increased seismicity or larger slip events from $7.3 \pm 0.7 \mathrm{kyr}$ to $10.2 \pm 1.9 \mathrm{kyr}$.

\section{Acknowledgments}

The financial support of the German Research Foundation (DFG, ME-4212/3-1, representative S. Mechernich) is gratefully acknowledged. We thank Niels Noack, Marco Politsch, Jakub Surma (University of Cologne, Germany) and Thomas Wiatr (RWTH Aachen, Germany) for several discussions and help during the fieldwork. Thanks to Christoph Hilgers (RWTH Aachen) and his team for the loan of the TLS system. René Paillard (University of Cologne) is thanked for his help with the sample preparation. Thanks also to Stefan Heinze (University of Cologne) for the ${ }^{36} \mathrm{Cl}$ measurements at CologneAMS, Lucilla Benedetti (Aix-Marseille University, France) for independent ${ }^{36} \mathrm{Cl}$ measurements at ASTER, and Clemens Prescher (University of Cologne) for using his server capacity. Detailed comments by the Associate Editor, Robin Lacassin and two anonymous reviewers, as well as the editorial handling by Uri ten Brink improved the quality of the manuscript significantly. Supporting data are included in the supporting information of this article.

\section{References}

Akaike, H. (1974), A new look at statistical model identification, IEEE Trans. Autom. Control, 19(6), $716-723$.

Ambraseys, N. N., and J. A. Jackson (1990), Seismicity and associated strain of central Greece between 1890 and 1988, Geophys. J. Int., 101, 663-708, doi:10.1111/j.1365246X.1990.tb05577.x.

Armijo, R., H. Lyon-Caen, and D. Papanastiassiou (1992), East-west extension and Holocene normalfault scarps in the Hellenic arc. Geology, 20, 491-494.

Armijo, R., B. Meyer, G. C. P. King, A. Rigo, and D. Papanastassiou (1996), Quaternary evolution of the Corinth Rift and its implications for the Late Cenozoic evolution of the Aegean, Geophys. J. Int., 126, 11-53.

Bastesen, E., A. Braathen, H. Nøttveit, R. H. Gabrielsen, and T. Skar (2009), Extensional fault cores in micritic carbonate - Case studies from the Gulf of Corinth, Greece, J. Str. Geol., 31, 403-420, doi:10.1016/j.jsg.2009.01.005.

Bell, R. E., L. C. McNeill, J. M. Bull, T. J. Henstock, R. E. L. Collier, and M. R. Leeder (2009), Fault architecture, basin structure and evolution of the Gulf of Corinth Rift, central Greece, Basin Res., 21, 824-855, doi: 10.1111/j.1365-2117.2009.00401.x.

Benedetti, L. R. Finkel, D. Papanastassiou, G. King, R. Armijo, F. Ryerson, D. Farber, and F. Flerit 
(2002), Post-glacial slip history of the Sparta fault (Greece) determined by ${ }^{36} \mathrm{Cl}$ cosmogenic dating: Evidence for non-periodic earthquakes, Geophys. Res. Lett., 29(8), 1246, doi:10.1029/2001GL014510.

Benedetti, L. R. Finkel, G. King, R. Armijo, D. Papanastassiou, F. J. Ryerson, F. Flerit, D. Farber, and G. Stavrakakis (2003), Motion on the Kaparelli fault (Greece) prior to the 1981 earthquake sequence determined from ${ }^{36} \mathrm{Cl}$ cosmogenic dating, Terra Nova, 15(2), 118-124.

Benedetti, L., I. Manighetti, Y. Gaudemer, R. Finkel, J. Malavieille, K. Pou, M. Arnold, G. Aumaître, D. Bourlès, and K. Keddadouche (2013), Earthquake synchrony and clustering on Fucino faults (Central Italy) as revealed from in situ 36Cl exposure dating, J. Geophys Res. Solid Earth, 118, 1-27, doi:10.1002/jgrb.50299.

Bornovas, J., P. Gaitanakis, and A. Spiridopoulos (1984), Geological Map of Greece, 1:50 000, Perachora Sheet. IGME, Athens.

Bosi, C. (1975), Osservazioni preliminari su faglie probabilmente attive nell'Appennino central, Bollettino Societa Geologica Italiana, 94, 827-859.

Bradwell, T. (2009), Lichenometric dating: A commentary, in the light of some recent statistical studies, Geografisika Annaler, 91(2), 61-69, doi:10.1111/j.1468-0459.2009.00354.x

Briole, P., A. Rigo, H. Lyon-Caen, J.C. Ruegg, K. Papazissi, C. Mitsakaki, A. Balodimou, G. Veis, D. Hatzfeld, and A. Deschamps (2000), Active deformation of the Corinth rift, Greece: Results from repeated Global Positioning System surveys between 1990 and 1995, J. Geophys. Res., 105(B11), 25605-25625, doi:10.1029/2000JB900148.

Brodsky, E. E., J. J. Gilchrist, A. Sagy, and C. Collettini (2011), Faults smooth gradually as a function of slip, Earth Planet Sci. Lett., 302, 185-193, doi:10.1016/j.epsl.2010.12.010.

Bubeck, A., M. Wilkinson, G. P. Roberts, P. A. Cowie, K. J. W McCaffrey, R. Phillips, and P. Sammonds (2015), The tectonic geomorphology of bedrock scarps on active normal faults in the Italian Apennines mapped using combined ground penetrating radar and terrestrial laser scanning, Geomorphology, 237, 38-51, doi:10.1016/j.geomorph. 2014.03.011.

Bull, W.B., J. King, F. Kong, T. Moutoux, and W.M. Phillips (1994), Lichen dating of coseismic landslide hazards in alpine mountains, Geomorphology, 10, 253-264, doi:10.1016/0169555X(94)90020-5.

Burnham, K. P., and D. R. Anderson (2002), Model Selection and Multi-Model Inference: A practical Information-Theoretical Approach, Springer, New York.

Caputo, R., B. Helly, S. Pavlides, and G. Papadopoulos (2004), Palaeoseismological investigation of the Tyrnavos Fault (Thessaly, Central Greece), Tectonophysics, 394, 1-20, doi:10.1016/j.tecto.2004.07.047.

Carcaillet, J., I. Manighetti, C. Chauvvel, A. Schlagenhauf, and J.-M. Nicole (2008), Identifying past earthquakes on an active normal fault (Magnola, Italy) from the chemical analysis of its exhumed carbonate fault plane, Earth Planet. Sci. Lett., 271, 145-158, doi:10.1016/j.epsl.2008.03.059.

Cerling, T. E., and H. Craig (1994), Cosmogenic ${ }^{3} \mathrm{He}$ production rates from $39^{\circ} \mathrm{N}$ to $46^{\circ} \mathrm{N}$ latitude, western USA and France, Geochim. Cosmochim. Acta, 58, 249-255.

Charalampakis, M., V. Lykousis, D. Sakellariou, G. Papatheodorou, and G. Ferentinos (2014), The tectono-sedimentary evolution of the Lechaion Gulf, the south eastern branch of the Corinth graben, Greece, Marine Geol., 351, 58-75, doi:10.1016/j.margeo.2014.03.014.

Clarke, P. J., R. R. Davies, P. C. England, B. E. Parsons, H . Billiris, D. Paradissis ,G . Veis, P. H. Denys, P. A. Cross, V. Ashkenazsi, and R. Bingley (1998), Crustal strain in central Greece from repeated GPS measurements in the interval 1989-1997, Geophys. J. Int., 135(1), 195-214, doi:10.1046/j.1365-246X.1998.00633.x.

Chen, J., H.-P. Blume, and L. Beyer (2000), Weathering of rocks induced by lichen colonization - a review, Catena, 39, 121-146.

Collier, R. E. L., D. Pantosti, G. D'Addezio, P. M. De Martini, E. Masana, and D. Sakellariou (1998), Paleoseismicity of the 1981 Corinth earthquake fault: Seismic contribution to extensional strain in central Greece and implications for seismic hazard, J. Geophys. Res., 103(B12), 30001-30019, doi:10.1029/98JB02643

Cowie, P. A., R. J. Phillips, G. P. Roberts, K. McCaffrey, L. J. J. Zijerveld, L. C. Gregory, J. Faure Walker, L. N. J. Wedmore, T. J. Dunai, S. A. Binnie, S. P. H. T. Freeman, K. Wilcken, R. P. Shanks, R. S. Huismans, I. Papanikolaou, A. M. Michetti, and M. Wilkinson (2017), Orogen- 
scale uplift in the central Italian Apennines drives episodic behaviour of earthquake faults. Sci. Rep., 7, 44858, doi: 10.1038/srep44858.

D’Amato, D., B. Pace, L. Di Nicola, F. M. Stuart, F. Visini, R. Azzaro, S. Branca, and D. N. Barfod (2017), Holocene slip rate variability along the Pernicana fault system (Mt. Etna, Italy): Evidence from offset lava flows, GSA Bulletin, 129(3-4), 304-317, doi: 10.1130/B31510.1

Deligiannakis, G., I. D. Papanikolaou, and G. Roberts (2018), Fault specific GIS based seismic hazard maps for the Attica region, Greece, Geomorphology, 306, 264-282, doi:10.1016/j.geomorph.2016.12.005

Drakopoulos, J., G. Leventakis, and A. Roussopoulos (1978), Microzonation in the seismic area of Corinth-Loutraki. Ann. Geofis. 31, 51-96, doi: 10.4401/ag-4743.

Dunai, T. J., S. A. Binnie, A. S. Hein, and S. M. Paling (2014), The effects of a hydrogen-rich ground cover on cosmogenic thermal neutrons: Implications for exposure dating, Quat. Grochron., 22, 183-191, doi:10.1016/j.quageo.2013.01.001.

Emmanuel, S., and Y. Levenson (2014), Limestone weathering rates accelerated by micron-scale grain detachment, Geology, 42(9), 751-754, doi:10.1130/G35815.1.

Evans, J.M., J. O. H. Stone, L. K. Fifield, and R.G. Cresswell, (1997), Cosmogenic chlorine-36 production in K-feldspar, Nucl. Instrum. Methods Phys. Res. B 123, 334-340, doi:10.1016/S0168-583X(96)00714-8.

Fink, D., S. Vogt, and M. Hotchkis, (2000), Cross-sections for ${ }^{36} \mathrm{Cl}$ from Ti at $\mathrm{E}_{\mathrm{p}}=35-150 \mathrm{MeV}$ : Applications to in-situ exposure dating, Nucl. Instrum. Methods Phys. Res. B 172, 861-866, doi:10.1016/S0168-583X(00)00200-7

Faure Walker J. P., G. P. Roberts, P. A. Cowie, I. D. Papanikolaou, P. R. Sammonds, A. M. Michetti, and R. J. Phillips (2009), Horizontal strain-rates and throw-rates across breached relay zones, central Italy: Implications for the preservation of throw deficits at points of normal fault linkage, J. Str. Geol., 31, 1145-1160, doi:10.1016/j.jsg.2009.06.011.

Friedrich, A. M., B. P. Wernicke, N. A. Niemi, R. A. Bennett, and J. L. Davis (2003), Comparison of geodetic and geologic data from the Wasatch region, Utah, and implications for the spectral character of Earth deformation at periods of 10 to 10 million years, J. Geophys. Res., 108(B4), 2199, doi:10.1029/2001JB000682.

Furlani, S., F. Cucchi, S. Biolchi, and R. Odorico (2011), Notchces in the Northern Adriatic Sea: Genesis and development, Quat. Int., 232, 158-168, doi:10.1016/j.quaint.2010.06.010

Giaccio, B., F. Galadini, A. Spasato, P. Messina, M. Moro, M. Zreda, A. Cittadini, S. Salvi, and A. Todero (2003), Image processing and roughness analysis of exposed bedrock fault planes as a tool for paleoseismological analysis: results from the Campo Felice fault (central Apennines, Italy). Geomorphology, 49, 281-301, doi:10.1016/S0169-555X(02)00191-5.

Goldberg, R., S. Siman-Tov, and S. Emmanuel (2016), Weathering resistance of carbonate fault mirrors promotes rupture localization, Geophys. Res. Lett., 43, 3105-3111, doi:10.1002/2016GL067788.

Gosse, J. C., and F. M. Phillips (2001), Terrestrial in situ cosmogenic nuclides: theory and application, Quat. Sci. Rev., 20, 1475-1560, doi:10.1016/S0277-3791(00)00171-2

Gran-Mitchell, S., A. Matmon, P. R. Bierman, Y. Enzel, M. Caffee, and D. Rizzo (2001), Displacement history of a limestone normal fault scarp, northern Israel, from cosmogenic ${ }^{36} \mathrm{Cl}$, J. Geophys. Res., 106(B3), 4247-4264, doi:10.1029/2000JB900373.

Gromig, R., S. Mechernich, A. Ribolini, B. Wagner, G. Zanchetta, I. Isola, M. Bini, and T. Dunai, (2018): Evidence for a Younger Dryas deglaciation in the Galicica Mountains (FYROM) from cosmogenic ${ }^{36} \mathrm{Cl}$. Quat. Int., 464 (Part B), 352-363, doi:10.1016/j.quaint.2017.07.013.

He, H., Z. Wei, and A. Densmore (2016), Quantitative morphology of bedrock fault surfaces and identification of paleo-earthquakes, Tectonophysics, 693A, 22-31, doi:10.1016/j.tecto.2016.09.032

Heisinger, B., D. Lal, A. J. T. Jull, P. Kubik, S. Ivy-Ochs, K. Knie, and E. Nolte (2002), Production of selected cosmogenic radionuclides by muons: 2. Capture of negative muons, Earth Planet. Sci. Lett., 200, 357-369, doi:10.1016/S0012-821X(02)00641-6.

Hubert, A., G. King, R. Armijo, B. Meyer, and D. Papanastasiou (1996), Fault re-activation, stress interaction and rupture propagation of the 1981 Corinth earthquake sequence, Earth Planet. Sci. Lett., 142, 573-585. 
IGME: Institute of Geological and Mining Research, 1984. Geologic map - Perachora sheet, 1:50.000. Jackson, J.A., J. Gagnepain, G. Houseman, G.C.P. King, P. Papadimitriou, C. Soufleris, and J. Virieux (1982), Seismicity, normal faulting, and the geomorphological development of the Gulf of Corinth (Greece)" the Corinth earthquakes of February and March 1981, Earth Planet. Sci. Lett., 57, 377-397.

Jolivet, L., C. Faccenna, B. Huet, L. Labrousse, L. Le Pourhiet, O. Lacombe, E. Lecomte, E. Burov, Y. Denèle, J.-P. Brun, M. Philippon, A. Paul, G. Salaün, H. Karabulut, C. Piromallo, P. Monié, F. Gueydan, A. I. Okay, R. Oberhänsli, A. Pourteau, R. Augier, L. Gadenne, and O. Driussi (2013), Aegean tectonics: Strain localisation, slab tearing and trench retreat, Tectonophysics, 597-598, 1-33, doi:10.1016/j.tecto.2012.06.011.

Jones, R. R., S. Kokkalas, and K. J. W. McCaffrey (2009), Quantitative analysis and visualization of nonplanar fault surfaces using terrestrial laser scanning (LIDAR) - The Arkitsa fault, central Greece, as a case study, Geosphere, 5(6), 465-482, doi:10.1130/GES00216.1.

Koukouvelas. I. K., V. Zygouri, G. A. Papadopoulos, and S. Verroios (2017), Holocene record of slippredictable earthquakes on the Kenchreai Fault, Gulf of Corinth, Greece, J. Str. Geol., 94, 258274, doi.org/10.1016/j.jsg.2016.12.001.

Koukouvelas, I. K., D. Katsonopoulou, S. Soter, and P. Xypolias (2005), Slip rates on the Helike Fault, Gulf of Corinth, Greece: new evidence from geoarchaeology, Terra Nova, 17, 158-164, doi: 10.1111/j.1365-3121.2005.00603.x.

Leeder, M. R., R. E. L. Collier, L. H. Abdul Aziz, M. Trout, G. Ferentinos, G. Papatheodorou, and E. Lyberis (2002), Tectono-sedimentary processes along an active marine/lacustrine half-graben margin: Alkyonides Gulf, E. Gulf of Corinth, Greece, Basin Res., 14(1), 25-41, doi:10.1046/j.1365-2117.2002.00164.x.

Leeder, M. R., C. Portman, J. E. Andrews, R. E. L. Collier, E. Finch, R. L. Gawthorpe, L. C. McNeill, M. Perez-Arlucea, and P. Rowe (2005), Normal faulting and crustal deformation, Alkyonides Gulf and Perachora peninsula, eastern Gulf of Corinth Rift, Greece, J. Geol. Soc. London, 162(3), 549-561, doi:10.1144/0016-764904-075.

Leeder, M. R., G. H. Mack, A. T. Brasier, R. R. Parrish, W. C. McIntosh, J. E. Andrews, and C. E. Duermeijer (2008), Late-Pliocene timing of Corinth (Greece) rift-margin fault migration, Earth Planet. Sci. Lett., 274(1-2), 132-141, doi:10.1016/j.eps1.2008.07.006.

Livio, F., A. M. Michetti, E. Vittori, L. Gregory, L. Wedmore, L. Piccardi, E. Tondi, G. Roberts, and Central Italy Earthquake Working Group (2016), Surface faulting during the August 24, 2016, Central Italy earthquake (Mw 6.0): preliminary results, Ann. Geophys, 59, Fast Track 5, doi:10.4401/ag-7197.

Lykousis, V., D. Sakellariou, I. Moretti, and H. Kaberi (2007), Late Quaternary basin evolution of the Gulf of Corinth: Sequence stratigraphy, sedimentation, fault-slip and subsidence rates, Tectonophysics, 440(1-4), 29-51, doi:10.1016/j.tecto.2006.11.007.

Lyon-Caen, H., Armijo, R., Drakopoulos, J., Baskoutass, J., Delibassis, N., Gaulon, R., Kouskouna, V., Latoussakis, J., Makropoulos, K., Papadimitriou, P., Papanastassiou, D., and Pedotti, G. (1988), The 1986 Kalamata (South Peloponnesus) Earthquake: Detailed study of a normal fault, evidences for east-west extension in the Hellenic Arc, J. Geophys. Res., 93(B12), 14,967-15,000, doi: 10.1029/JB093iB12p14967.

Mariolakos, I., Papanikolaou, D., Symeonidis, N., Lekkas, S., Karotsieris, Z., and Sideris, C. (1982), The deformation of the area around the eastern Korinthian gulf, affected by the earthquakes of February-March 1981, Proceedings of International Symposium on the Hellenic Arc and Trench (H.E.A.T.), 1. National Technical University, Athens, 400-420.

Marrero, S.M., Phillips, F.M., Caffee, M.W., Gosse, J.C., 2016. CRONUS-Earth cosmogenic ${ }^{36} \mathrm{Cl}$ calibration. Quat. Geochronol. 31, 199-219, doi:10.1016/j.quageo.2015.10.002.

Mason, J., S. Schneiderwind, A. Pallikarakis, T. Wiatr., S. Mechernich, I. Papanikoloau, and K. Reicherter (2016), Fault structure and deformation rates at the Lastros-Sfaka Graben, Crete, Tectonophysics, 683, 216-232, doi:10.1006/j.tecto.2016.06.036.

Mason, J., S. Schneiderwind, A. Pallikarakis, S. Mechernich, I. Papanikoloau, and K. Reicherter (2017), Hanging-wall colluvial cementation along active normal faults, Quat. Res., 88, 39-59, doi:10.1017/qua.2017.32.

Mechernich, S., T. J. Dunai, S. A. Binnie, T. Goral, S. Heinze, A. Dewald, L. Benedetti, I. 
Schimmelpfennig, F. Phillips, S. Marrero, M. A. Sarıkaya, L. C. Gregory, R. J. Phillips, K. Wilcken, K. Simon, and D. Fink (2017), Carbonate and silicate rock standards for cosmogenic ${ }^{36} \mathrm{Cl}$, Geophys. Res. Abstr., 19, EGU2017-10093.

Mildon, Z. K., G. P. Roberts, J. P. Faure Walker, L. N. J. Wedmore, and K. J. W. McCaffrey (2016), Active normal faulting during the 1997 seismic sequence in Colfiorito, Umbria: Did slip propagate to the surface? J. Str. Geol., 91, 102-113, doi:10.1016/j.jsg.2016.08.011.

Maroukian, H., K. Gaki-Papanastassiou, E. Karymbalis, K. Vouvalidis, K. Pavlopoulos, D. Papanastassiou, and K. Albanakis (2008), Morphotectonic control on drainage network evolution in the Perachora Peninsula, Greece, Geomorphology, 102, 81-92, doi:10.1016/j.geomorph.2007.07.021.

Moretti, I., D. Sakellariou, V. Lykousis, and L. Micarelli (2003), The Gulf of Corinth: an active half graben? J. Geodyn., 36, 323-340, doi:10.1016/S0264-3707(03)00053-X.

Morewood, N.C., and G. P. Roberts, (2001), Comparison of surface slip and focal mechanism slip data along normal faults: an example from the eastern Gulf of Corinth, Greece, J. Str. Geol., 23, 473-487.

Morewood, N.C., and G.P. Roberts (2002), Surface observations of active normal fault propagation: implications for growth, J. Geol. Soc. London, 159, 263-272.

Mottershead, D., and G. Lucas, (2001), Field testing of Glew and Ford's model of solution flute evolution, Earth Surf. Proc. Landf., 26, 839-846, doi:10.1002/esp.229.

Nixon, C. W., L. C. McNeill, J. M. Bull, R. E. Bell, R. L. Gawthorpe, T. J. Henstock, D. Christodoulou, M. Ford, B. Taylor, D. Sakellariou, G. Ferentinos, G. Papatheodorou, M. R. Leeder, R. E.L. Collier, A. M. Goodliffe, M. Sachpazi, and H. Kranis (2016), Rapid spatiotemporal variations in rift structure during development of the Corinth Rift, central Greece, Tectonics, 35, 1225-1248, doi:10.1002/2015TC004026.

Paradise, T. R. (1998), Limestone weathering and rate variability, great temple of Amman, Jordan, Phys. Geogr., 19(2), 133-146.

Papanikolaou, D., V. Lykousis, G. Chronis, and P. Pavlakis (1988), A comparative study of neotectonic basins across the Hellenic arc: the Messiniakos, Argolikos, Saronikos and Southern Evoikos Gulfs, Basin Res., 1, 167-176.

Papanikolaou, I.D., G. P. Roberts, and A. M. Michetti, (2005), Fault scarps and deformation rates in Lazio-Abruzzo, Central Italy: comparison between geological fault slip-rate and GPS data, Tectonophysics, 408, 147-176, doi:10.1016/j.tecto.2005.05.043.

Papanikolaou, I.D., M. Triantaphyllou, A. Pallikarakis, and G. Migiros (2015a), Active faulting at the Corinth Canal based on surface observations, borehole data and paleoenvironmental interpretations. Passive rupture during the 1981 earthquake sequence? Geomorphology, 237, 6578, doi:10.1016/j.geomorph.2014.10.036.

Papanikolaou, I.D., R. van Balen, P.G. Silva, and K. Reicherter (2015b), Geomorphology of active faulting and seismic hazard assessment: new tools and future challenges. Geomorphology, 237, 1-13, doi:10.1016/j.geomorph.2015.02.024.

Papazachos, C. B., and C. A. Papaioannou (1997), Macroseismic field of the Balkan area, J. Seismology, 1, 181-201, doi:10.1023/A:1009709112995.

Pavlides, S., and R. Caputo (2004), Magnitude versus faults' surface parameters: quantitative relationships from the Aegean Region, Tectonophysics, 280, 159-188, doi: $10.1016 /$ j.tecto.2003.09.019

Pizzi, A., A. Di Domenica, F. Gallovič, L. Luzi, and R. Puglia (2017), Fault segmentation as constraint to the occurrence of the main shocks of the 2016 Central Italy seismic sequence, Tectonics, 36, doi:10.1002/2017TC004652.

Plug, L. J., J. C. Gosse, J. J. McIntosh, and R. Bigley (2007), Attenuation of cosmic ray flux in temperate forest, J. Geophys. Res., 112, F02022, doi:10.1029/2006JF000668.

Pucci, S., P. M. De Martini, R. Civico, F. Villani, R. Nappi, T. Ricci, R. Azzaro, C. A. Brunori, M. Caciagli, F. R. Cinti, V. Sapia, R. De Ritis, F. Mazzarini, S. Tarquini, G. Gaudiosi, R. Nave, G. Alessio, A. Smedile, L. Alfonsi, L. Cucci, and D. Pantosti (2017), Coseismic ruptures of the 24 August 2016, Mw 6.0 Amatrice earthquake (central Italy), Geophys. Res. Lett., 44, 2138-2147, doi:10.1002/2016GL071859. 
Reilinger, R., S. McClusky, D. Paradissis, S. Ergintav, and P. Vernant (2010), Geodetic constraints on the tectonic evolution of the Aegean region and strain accumulation along the Hellenic subduction zone, Tectonophysics, 488, 22-30, doi:10.1016/j.tecto.2009.05.027.

Riley, S., S.D. DeGloria, and R. Elliot (1999), A terrain ruggedness index that quantified topographic heterogeneity, Intermt. J. Sci., 5, 23-27.

Rixhon, G., S.M. May, M. Engel, S. Mechernich, A. Schroeder-Ritzrau, N. Frank, J. Fohlmeister, F. Boulvain, T. Dunai, and H. Brückner (2018), Multiple dating approach $\left({ }^{14} \mathrm{C}\right.$, U/Th and $\left.{ }^{36} \mathrm{Cl}\right)$ of tsunami-transported reef-top boulders on Bonaire (Leeward Antilles) - Current achievements and challenges, Marine Geol., 396, 100-113, doi: 10.1016/j.margeo.2017.03.007.

Roberts, G. P. (1996a), Variation in fault-slip directions along active and segmented normal fault systems, J. Str. Geol., 18, 835-845.

Roberts, G. P. (1996b), Noncharacteristic normal faulting surface ruptures from the Gulf of Corinth, Greece, J. Geophys. Res.: Solid Earth, 101(B11), 25,255-25,267. doi/10.1029/96JB02119.

Roberts, G. P., and I. Stewart (1994), Uplift, deformation and fluid involvement within an active normal fault zone in the Gulf of Corinth, Greece, J. Geol. Soc. London, 151, 531-541, doi:10.1144/gsjgs.151.3.0531.

Roberts, G. P., Papanikolaou, I., Vött, A., Pantosti, D., and Hadler, H. (2011). Active Tectonics and Earthquake Geology of the Perachora Peninsula and the Area of the Isthmus, Corinth Gulf, Greece. In: Roberts, G., Papanikolaou, I., Vött, A., Pantosti, D., Hadler, H. (eds). INQUA TERPRO Focus Area on Paleoseismology and Active Tectonics \& IGCP-567 Earthquake Archaeology, Athens, $40 \mathrm{pp}$.

Roberts, G. P., and A. Ganas (2000), Fault-slip directions in central and southern Greece measured from striated and corrugated fault planes' Comparison with focal mechanism and geodetic data, J. Geophys. Res. 105(B10), 23,443-23,46, doi:10.1029/1999JB900440

Roberts, G. P., A. M. Michetti, P. Cowie, N. C. Morewood, and I. Papanikolaou (2002), Fault slip-rate variations during crustal-scale strain localisation, central Italy, Geophys, Res. Lett., 29(8), 1168, doi:10.1029/2001GL013529.

Ryb, U., A. Matmon, Y. Erel, I. Haviv, L. Benedetti, and A. J. Hidy (2014), Styles and rates of longterm denudation in carbonate terrains under a Mediterranean to hyper-arid climatic gradient, Earth Planet. Sci. Lett., 406, 142-152, doi.org/10.1016/j.eps1.2014.09.008.

Sakellariou, D., V. Lykousis, S. Alexandri, H. Kaberi, G. Rousakis, P. Nomikou, P. Georgiou, and D. Ballas (2007), Faulting, seismic-stratigraphic architecture and Late Quaternary evolution of the Gulf of Alkyonides Basin-East Gulf of Corinth, Central Greece, Basin Res., 19(2), 273-295, doi:10.1111/j.1365-2117.2007.00322.x.

Schimmelpfennig, I., L. Benedetti, R. Finkel, R. Pik, P.-H. Blard, D. Bourlès, P. Burnard, and A. Williams (2009), Sources of in-situ ${ }^{36} \mathrm{Cl}$ in basaltic rocks. Implications for calibration of production rates, Quat. Geochronol., 4(6), 441-461, doi: 10.1016/j.quageo.2009.06.003.

Schlagenhauf, A., Y. Gaudemer, L. Benedetti, I. Manighetti, L. Palumbo, I. Schimmelpfennig, R. Finkel, and K. Pou (2010), Using in situ Chlorine-36 cosmonuclide to recover past earthquake histories on limestone normal fault scarps: a reappraisal of methodology and interpretations, Geophys. J. Int., 182, 36-72, doi:10.1111/j.1365-246X.2010.04622.x.

Schlagenhauf, A., I. Manighetti, L. Benedetti, Y. Gaudemer, R. Finkel, J. Malavieille, and K. Pou (2011), Earthquake supercycles in Central Italy, inferred from ${ }^{36} \mathrm{Cl}$ exposure dating, Earth Planet. Sci. Lett., 307(3-4), 487-500, doi:10.1016/j.eps1.2011.05.022.

Schmidt, S., R. Hetzel, F. Mingorance. and V.A. Ramos (2011), Coseismic displacements and Holocene slip rates for two active thrust faults at the mountain front of the Andean Precordillera $\left(\sim 33^{\circ} \mathrm{S}\right)$. Tectonics 30, TC5011, doi: 10.1029/2011TC002932.

Schneiderwind, S., J. Mason, T. Wiatr, I.D. Papanikolaou, and K. Reicherter, (2016), 3-D visualisation of palaeoseismic trench stratigraphy and trench logging using terrestrial remote sensing and GPR - a multiparametric interpretation, Solid Earth 7(2), 323-340. doi:10.5194/se-7323-2016.

Sharma, P., Kubik, P.W., Fehn, U., Gove, G.H., Nishiizumi, K., Elmore, D., 1990. Development of ${ }^{36} \mathrm{Cl}$ standards for AMS. Nucl. Inst. Methods Phys. Res. B, 52(3-4), 410-415, doi:0.1016/0168583X(90)90447-3. 
Smith, M. W. (2015), Direct acquisition of elevation data: Terrestrial Laser Scanning. Edited by British Society for Geomorpholgy, Geomorphological Techniques, Ch. 2, Sec. 1.5.

Stephenson, W. J., and B. L. Finlayson (2009), Measuring erosion with the micro-erosion meter Contributions to understanding, landform evolution, Earth-Sci. Rev., 95, 53-62, doi:10.1016/j.earscirev.2009.03.006.

Stewart, I.S. (1996), A rough guide to limestone fault scarps, J. Struct. Geol., 18, 1259-1264.

Stewart, I.S., and P. L. Hancock (1990a), What is a fault scarp, Episodes, 13(4), 256-263.

Stewart, I.S., and P. L. Hancock (1990b), Brecciation and fracturing within neotectonic normal fault zones in the Aegean region. In: R.J. Knipe, E.H. Rutter, (Eds.), Deformation Mechanisms, Rheology and Tectonics. Geol. So. London, Spec. Pub., 54, 05-112.

Stewart, I.S., and P. L. Hancock (1991), Scales of structural heterogeneity within neotectonic normal fault zones in the Aegean region. J. Struct. Geol., 13, 191-204, doi:10.1016/01918141(91)90066-R.

Stone, J. O., G. L. Allan, L. K. Fifeld, and R. G. Cresswell (1996), Cosmogenic chlorine-36 from calcium spallation, Geoch. Cosmochim. Acta, 60(4), 679-692, doi:10.1016/0016-7037(95)004297.

Stone, J. O. (2000), Air pressure and cosmogenic isotope production, J. Geophys. Res., 105(B10), 23,753-23,759, doi:10.1029/2000JB900181.

Stone, J. O. (2005), Terrestrial Chlorine-36 Production from Spallation of Iron, $10^{\text {th }}$ AMS Conference, Berkeley.

Tesson, J., B. Pace, L. Benedetti, F. Visini, M. Delli Rocioli, M. Arnold, G. Aumaître, D. L. Bourlès, and K. Keddadouche (2016), Seismic slip history of the Pizzalto fault (central Apennines, Italy) using in situ-produced $36 \mathrm{Cl}$ cosmic ray exposure dating and rare earth element concentrations, J. Geophys. Res. Solid Earth, 121, doi:10.1002/2015JB012565.

Török, Á. (2003), Surface strength and mineralogy of weathering crusts on limestone buildings in Budapest, Build. and Environ., 38(9-10), 1185-1192, doi: 10.1016/S0360-1323(03)00072-6.

Thomas, F., V. Godard, O. Bellier, E. Shabanian, V. Ollivier, L. Benedetti, M. Rizza, N. Espurt, V. Guillou, F. Hollender, S. Molliex, and ASTER Team (2017), Morphological controls on the dynamics of carbonate landscapes under a mediterranean climate. Terra Nova, 29(3), 173-182, doi:10.1111/ter.12260.

Tsodoulos I.M., I. K. Koukouvelas, and S. Pavlides, S. (2008), Tectonic geomorphology of the easternmost extension of the Gulf of Corinth (Beotia, Central Greece). Tectonophysics, 453, 211 232, doi:10.1016/j.tecto.2007.06.015.

Villani, F., R. Civico, L. Pizzimenti, S. Pucci, P.M. De Martini, R. Nappi, and Open EMERGEO Working Group (2017): Coseismic surface geological effects following the 30 October $2016 \mathrm{M}_{\mathrm{w}}$ 6.5 earthquake, central Italy. PANGAEA, doi:10.1594/PANGAEA.879469, Supplement to: Villani, F et al. (in review): A database of the coseismic effects following the 30 October 2016 Norcia earthquake in Central Italy. Scientific Data.

Wallace, R. W. (1984), Faulting Related to the 1915 Earthquakes in Pleasant Valley, Nevada, U.S. Geological survey professional paper, 1274-A, B, A1-A33.

Wei, Z., H. He, and F. Shi (2013), Weathering history of an exposed bedrock fault surface interpreted from its topography, J. Struct. Geol., 56, 34-44, doi:10.1016/j.jsg.2013.08.008.

Wells, D.L., and K.J. Coppersmith (1994), New Empirical Relationships among Magnitude, Rupture Length, Rupture Width, Rupture Area, and Surface Displacement, Bulletin of the Seismological Society of America 84, 974-1002.

Wiatr, T. (2015), "t-LiDAR applications of active normal bedrock faults", doctoral dissertation, Rheinisch -Westfälische Technische Hochschule Aachen, 152 pages. Retrieved from https://publications.rwth-aachen.de/record/481178/files/481178.pdf

Wiatr, T., I. Papanikolaou, T. Fernández-Steeger, and K. Reicherter (2015), Bedrock fault scarp history: Insight from t-LiDAR backscatter behaviour and analysis of structure changes. Geomorphology 228, 421-431. doi:10.1016/j.geomorph.2014.09.021.

Wilkinson, M., G. P. Roberts, K. McCaffrey, P. A. Cowie., J. P. Faure Walker, I. D. Papanikolaou, R. J. Phillips, A.M. Michetti, E. Vittori, L. Gregory, L. Wedmore, and Z. K. Watson (2015), Slip distributions on active normal faults measured from LiDAR and field mapping of geomorphic 
offsets: an example from L'Aquila, Italy, and implications for modelling seismic moment release. Geomorphology, 237, 130-141. doi:10.1016/j.geomorph.2014.04.026.

Zreda, M., and J. S. Noller (1998), Ages of prehistoric earthquakes revealed by cosmogenic chlorine36 in a bedrock fault scarp at Hebgen lake, Science 282, 1097-1099.

Zygouri, V., S. Verroios, S. Kokkalas, P. Xypolias, and I. K. Koukouvelas, (2008), Scaling properties within the Gulf of Corinth, Greece; comparison between offshore and onshore active faults. Tectonophysics, 453, 193-210, doi:10.1016/j.tecto.2007.06.01.

\section{Figure captions}

Figure 1. (a) Location of the Corinth rift in SE Europe. (b) Seismotectonic map of the wider Corinth rift area. Major active faults from Jolivet et al. [2013] and seismicity from 1900 to 2017 (International Seismological Center (ISC)). (c) Major faults in the eastern Corinth rift on ASTER-GDEM V2 topography. Offshore faults after Papanikolaou et al. [1988]; Bell et al. [2009]; Charalampakis et al. [2014]; Sakellariou et al. [2007]; Zygouri et al. [2008]. Onshore faults after Goldsworthy et al. [2002]; Tsodoulos et al. [2008]; Papanikolaou et al. [2015a]; Koukouvelas et al. [2017], and our own fieldwork. Available extension rates are from Charalampakis et al. [2014], Deligiannakis et al. [2018], Koukouvelas et al. [2017] and own observations.

Figure 2. (a) Neotectonic map of the Perachora Peninsula drawn on the geomorphic map of GeoMapApp Version 3.6.3. The sections, which ruptured during the 1981 earthquakes, are indicated as bold lines. HER: Heraion fault; LL: Lower Loutraki fault; UL: Upper Loutraki fault. C98: Collier et al. [1998]; J82: Jackson et al. [1982]; MR02: Morewood and Roberts [2002]; W15: Wiatr et al. [2015]. (b) Oblique view of the central Pisia fault on the Google Earth image from 09/30/2014. The white lines point to the main study sites and the viewpoint of the photo in $\mathrm{c}$ is indicated. The distance from W15 to P7 is $200 \mathrm{~m}$, and $480 \mathrm{~m}$ from P7 to P19. (c) Photograph looking along the Pisia and Skinos normal fault scarps. (d, e) Orientation of the Pisia fault dip direction and striation for (d) the central Pisia fault within $2 \mathrm{~km}$ from the site of Wiatr et al. (2015), and (e) within $5 \mathrm{~m}$ of the sampling site.

Figure 3. Topographic profiles at sites $\mathrm{P} 6$ and $\mathrm{P} 7$ obtained from measurements using a clinometer and a scalebar. The profiles reveal the fault scarp height and geometry, which are used as input parameters for the cosmogenic nuclide modeling.

Figure 4. Sketch of an active bedrock fault scarp with different characteristic features on the fault plane [after Giaccio et al., 2002 and Wiatr, 2015]. Features like contrasting surface color, biokarstic pitting, lichen colonization and solution flute development often correlate with relative exposure duration. This allows the discrimination of several exhumation steps on the fault plane (EQ1, EQ2, etc.). Note that not all features need to occur for each exhumation step. Structural and textural features need to be identified to avoid a misinterpretation as weathering features.

Figure 5. Visually detected horizons on the fault plane of the Pisia normal fault (unedited photographs are provided in Fig. S1). The colored arrows point to the major detection criteria and the numbers refer to the height of the stripes above the scarp base. The sites occur along $600 \mathrm{~m}$ of the central Pisia fault and their location is marked in figure 2b. (a) Site P4: horizons 1 and 2 (EQ1, EQ2) were identified by color and lichen growth differences, horizon EQ3 by degradation and erosion. (b) Overview of site P7 in the foreground and site P6 in the background. (c, d) Details of site P6. Horizon EQ1 was identified by color differences, horizon EQ2 by a clear horizontal pitting band, horizon EQ3 by pitting and terminating solution flutes, horizon EQ4 by a pitting band, and horizons EQ5, EQ6a, and EQ6b by terminating solution flutes. Several horizontal orientated fractures intersect the main fault plane at $\sim 15^{\circ}$, meaning they are likely Riedel shears, or tensile fractures. Additional photographs of this site are shown in figures S2 and S3. (e) Agisoft PhotoScan merge of site P19, horizon EQ1 is identified by color and lichen growth differences, horizon EQ2 by increasing lichen size and 
additional lichen species as well as pitting and solution flute size. The location of horizons EQ3 and EQ4 is less certain due to the limited amount of solution flute indicators.

Figure 6. (a) 1981 coseismic displacement along the Pisia (red dots) and Skinos faults (blue dots) and their extrapolation (colored lines) [after Jackson et al., 1982 and Roberts and Ganas, 2000]. The exact measurement locations of Jackson et al. [1982] are not available so that their comparison at specific locations is not possible. The colored arrows show the 1981 slip direction after Jackson et al. [1982]. (b) Mapped coseismic displacements for the three lowermost horizons on the central Pisia fault using the criteria of color, lichen and karst development. The horizons at location W15 are derived from the laser scanning study of Wiatr et al. [2015]. Photographs of the sites P4, P6, P7, and P19 are shown in figure 5.

Figure 7. Terrestrial laser scanning (TLS) analyses at site P6; The unedited data is provided in figure S4. (a-c) Spatial visualization of surface characteristics. Subhorizontal dashed lines mark detected changes of surface properties on the TLS maps (black), or from the visual observations (grey). The legend below the maps defines the seven classes of TRI ruggedness, the relative backscatter intensity, and the ten iterative self-organizing (ISO) clusters of the backscattered data. The significance of the ISO clusters is shown in the dendrogram where all ten clusters are of comparable distinction and do not significantly vary in intercluster similarity linkage. (d-g) Profiles of the average TLS data along the scarp height using the yellow boxes on each side of the rock sampling profile shown in (a-c). The blue and red lines represent the average values of the respective profile and the dotted lines show their $1 \sigma$ deviations. Vertical turquoise lines indicate locations of surface property change related to the surface exposure duration. Dashed turquoise lines are set for orientation of additional detected changes from the visual detection and TLS maps. (h) The table on the upper right provides a scaled summary of the detected horizons using different methods. The colored bars show the uncertainties on horizon height for the respective method. Lighter bars indicate possible horizons with few indicators. The respective earthquake magnitudes were calculated after Wells and Coppersmith [1994] using the horizons as coseismic offset indicators.

Figure 8. ${ }^{36} \mathrm{Cl}$ concentrations ( $1 \sigma$ deviations) as a function of the height up the scarp (distance measured on the free-face). Horizontal lines correspond to major discontinuities identified by the surface weathering analyses and were modeled as earthquake event horizons. Minor fluctuations in the shape of the modeled ${ }^{36} \mathrm{Cl}$ concentrations (orange envelope) derived from chemical differences and their effect on the production rates. The two samples measured by ASTER (French AMS) highlight the measurement reliability (they were excluded from the modeling). (a) Manually approached model of highest likelihood according to the RMWs, AiCc, $\chi^{2}$ criteria. (b) Close-up view; blue circles are as in (a), whereas pink circles are modeled using different ages and recurrence intervals for EQs2-4. The likelihood of case (b) is only slightly lower. The upper part of the fault scarp is not influenced by this change. (c) Range of scenarios with a fit of RMSw $<7.0$, AiCc $<1870$ and $\chi^{2}<250$ and according age ranges.

Figure 9. The exhumation history of the free-face at site P6. (a) Modeling results of the manual iteration (see figure $8 \mathrm{a}, \mathrm{c}$ ). The slip rate was $0.5-0.6 \mathrm{~mm} / \mathrm{yr}$ for the last $\sim 7.3 \mathrm{kyr}(1.1-5.15 \mathrm{~m}$ ). For the upper part of the free-face (5.15-8.45 m; hypothetical earthquake offsets) the exhumation occurred at a significantly higher rate. (b) Earthquake history modeling scenarios using the MCMC Matlab ${ }^{\circledR}$ code of Cowie et al. [2017]. The range of slip rates for the 100 most likely models are given in turquois. Please note that the apparent slip history of the degraded scarp and the scarp age are hypothetical due to significant erosion, sedimentation at the scarp base and a lack of cosmogenic data.

Figure 10. Neotectonic faults and their slip rate estimates in the Perachora area (eastern Corinth rift) drawn on the geomorphic map of GeoMapApp Version 3.6.3. The latest ruptured fault segments are indicated in bold. The SAFS is composed of the north-dipping colored faults. The slip rates were partly updated compared to the original publications (see text S3). Areas with observed coastal uplift and subsidence indicate the dominance of nearby respective faults. HER: Heraion fault; LL: Lower Loutraki fault; UL: Upper Loutraki fault. A96: Armijo et al. [1996]; B09: Bell et al. [2009]; C98: 
1072 Collier et al. [1998]; J82: Jackson et al. [1982]; L02: Leeder et al. [2002]; L05: Leeder et al. [2005]; 1073 MR02: Morewood and Roberts [2002]; R11: Roberts et al. [2011]; S07: Sakellariou et al. [2007]. 


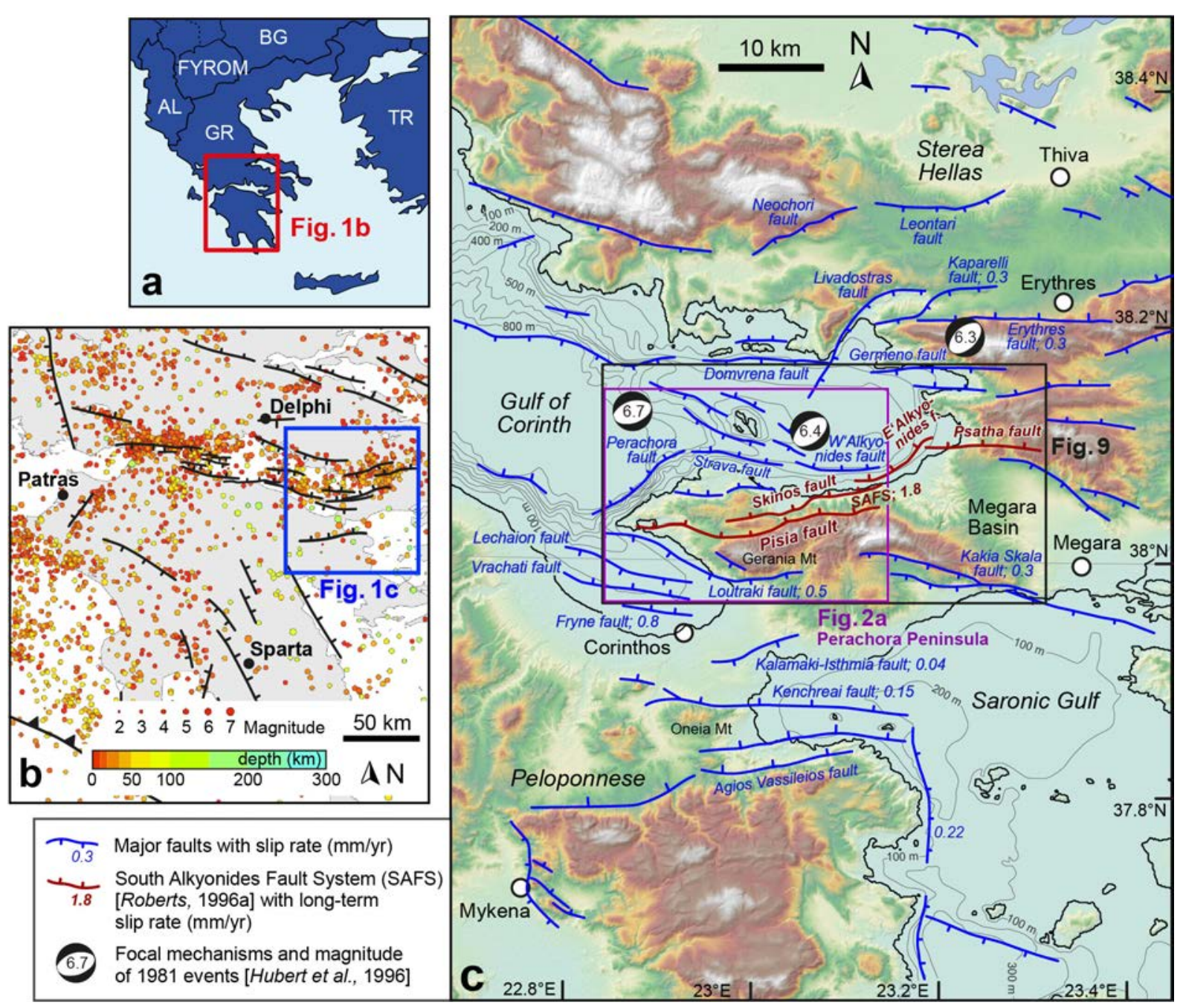

$1074 \quad$ Figure 1 

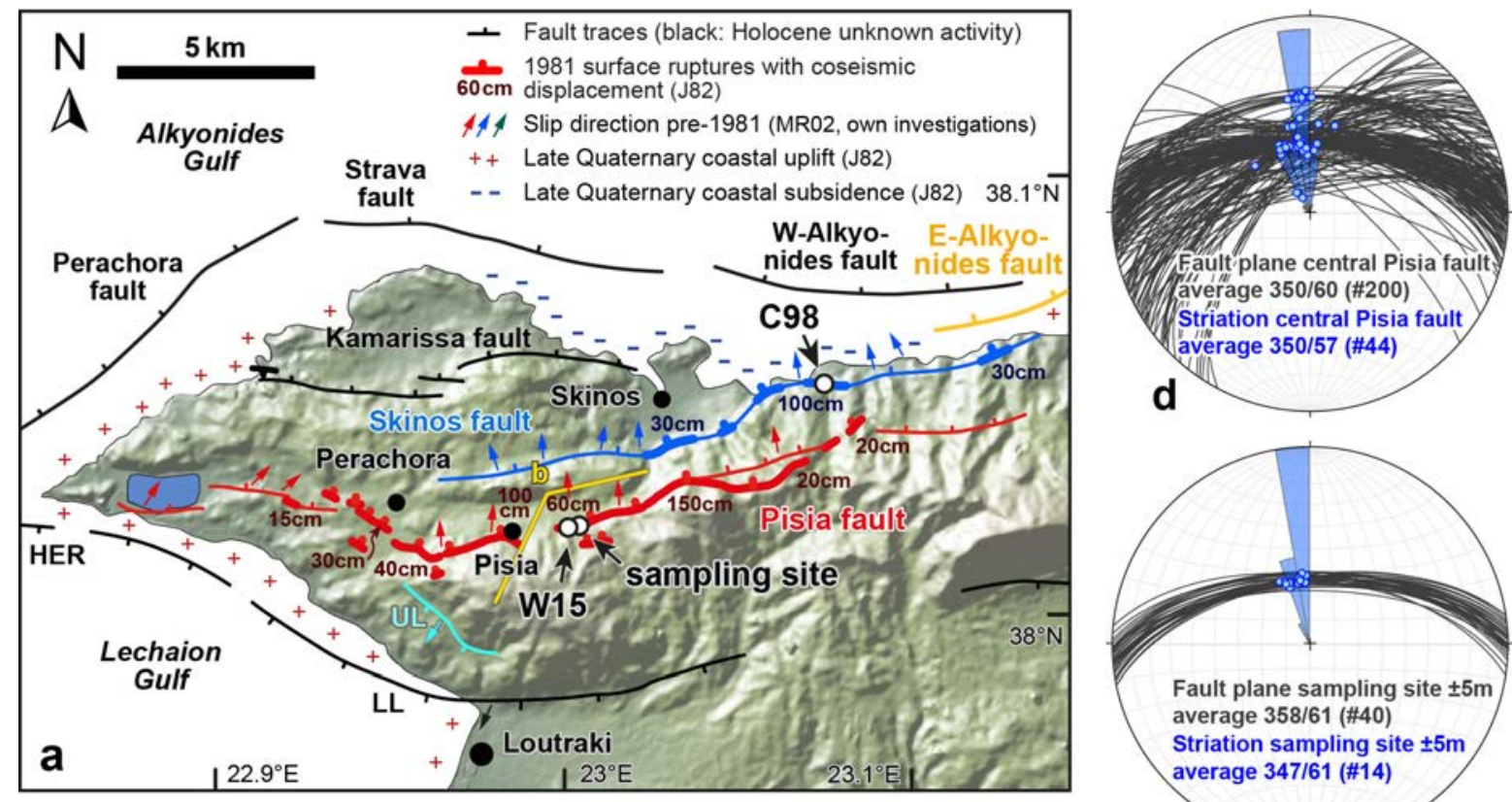

Fault plane sampling site $\pm 5 \mathrm{~m}$ average 358/61 (\#40)

Striation sampling site $\pm 5 \mathrm{~m}$ average 347/61 (\#14)

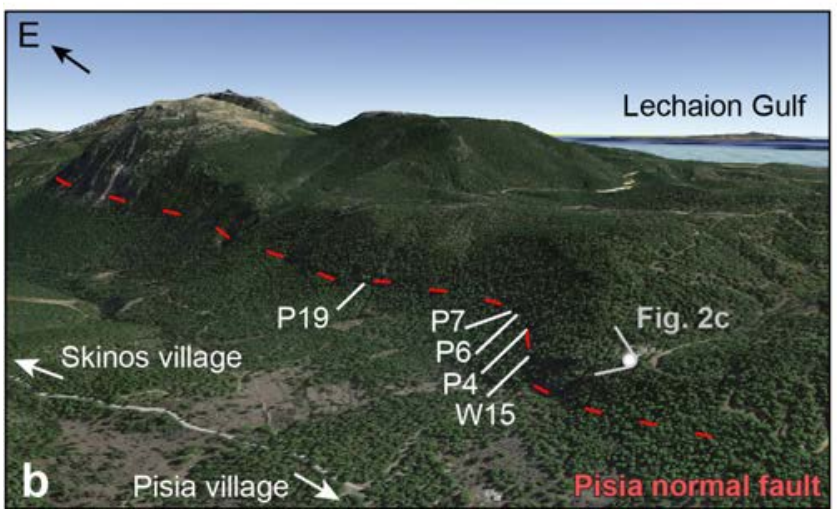

e

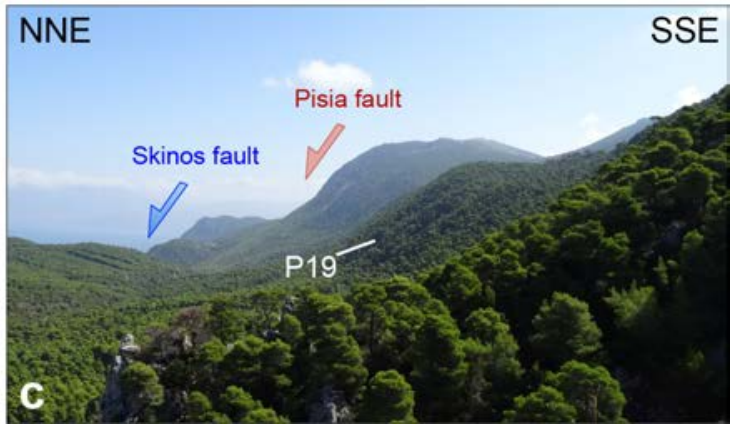

Figure 2 
1077

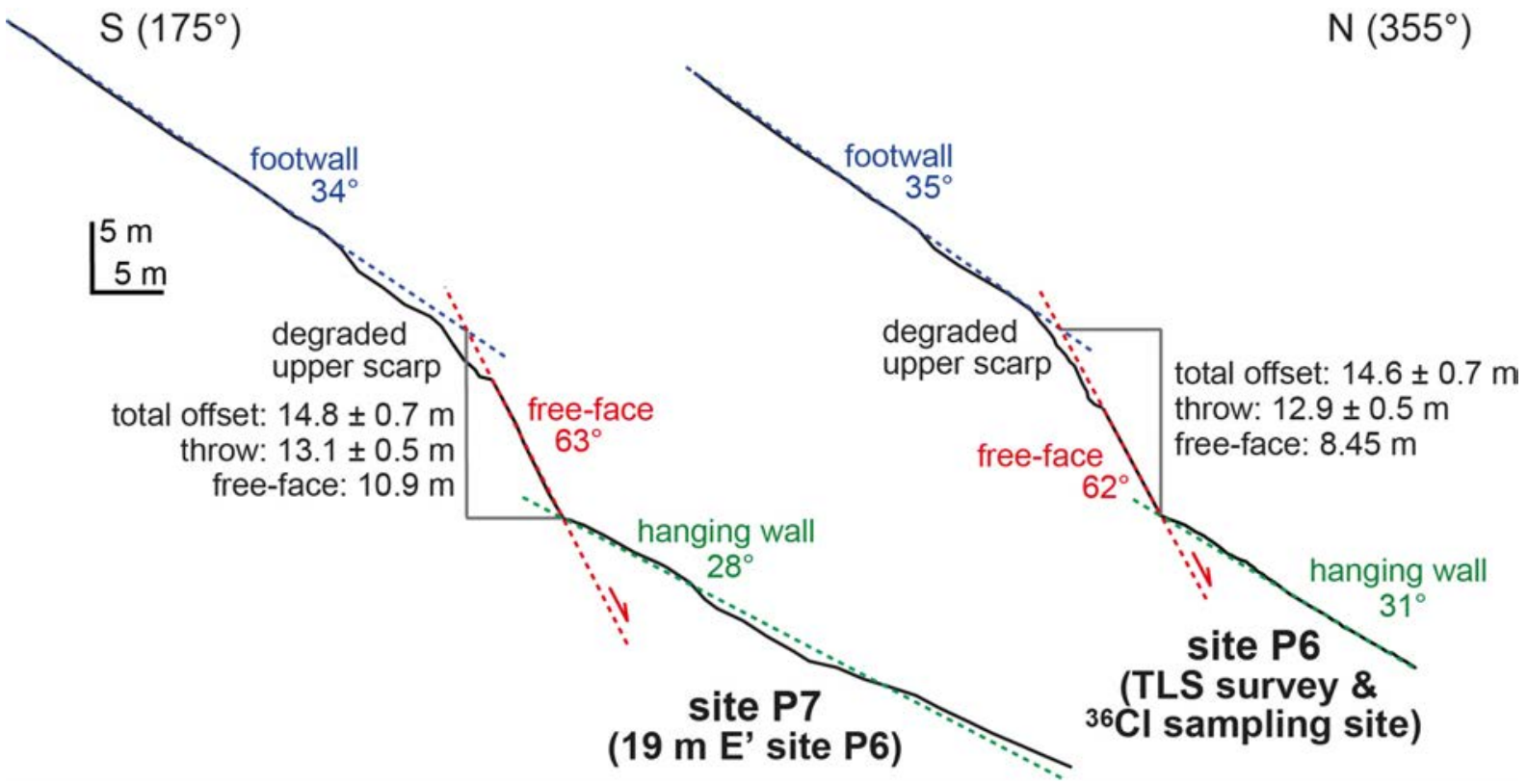

Figure 3 


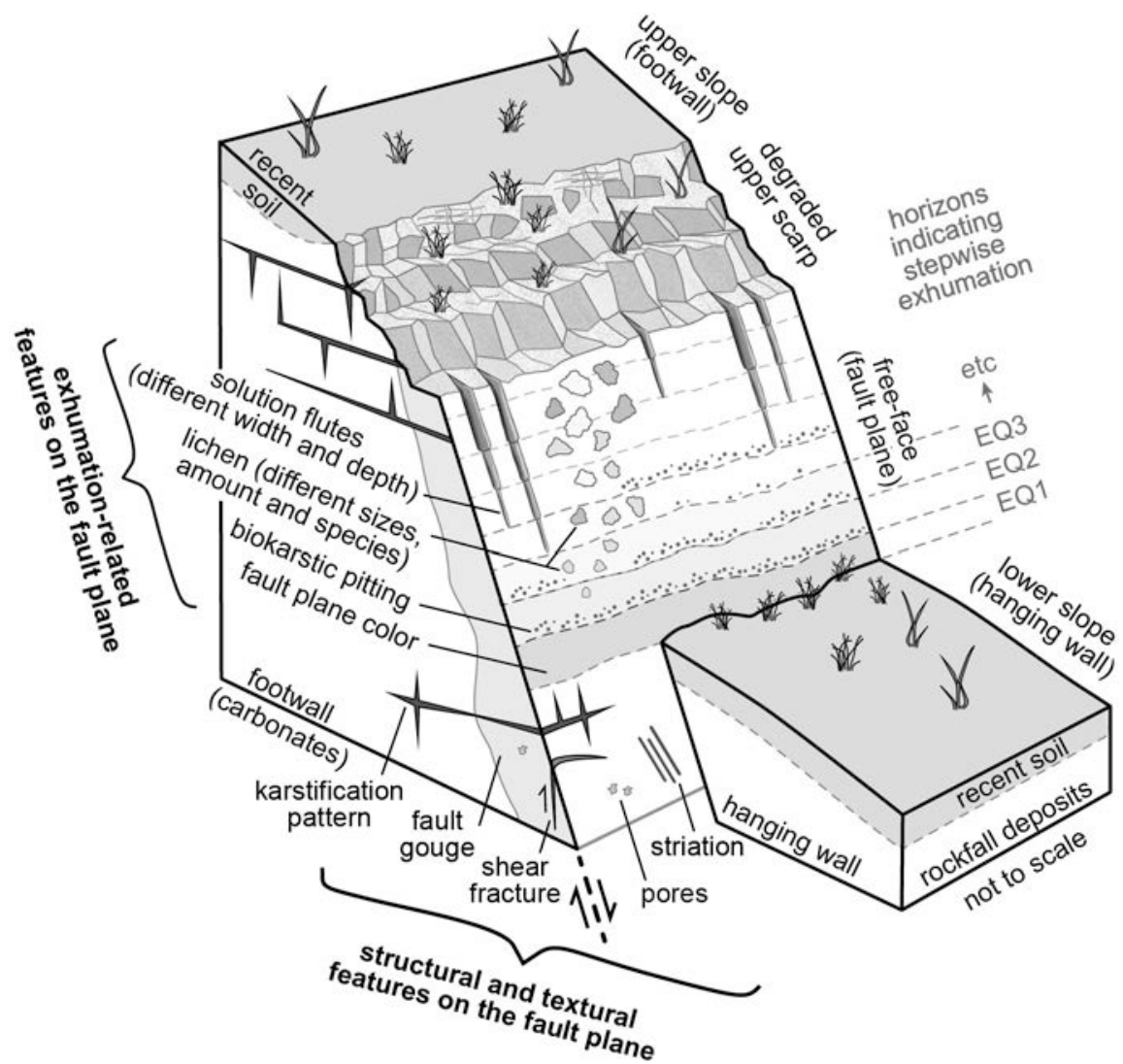

1082 Figure 4 

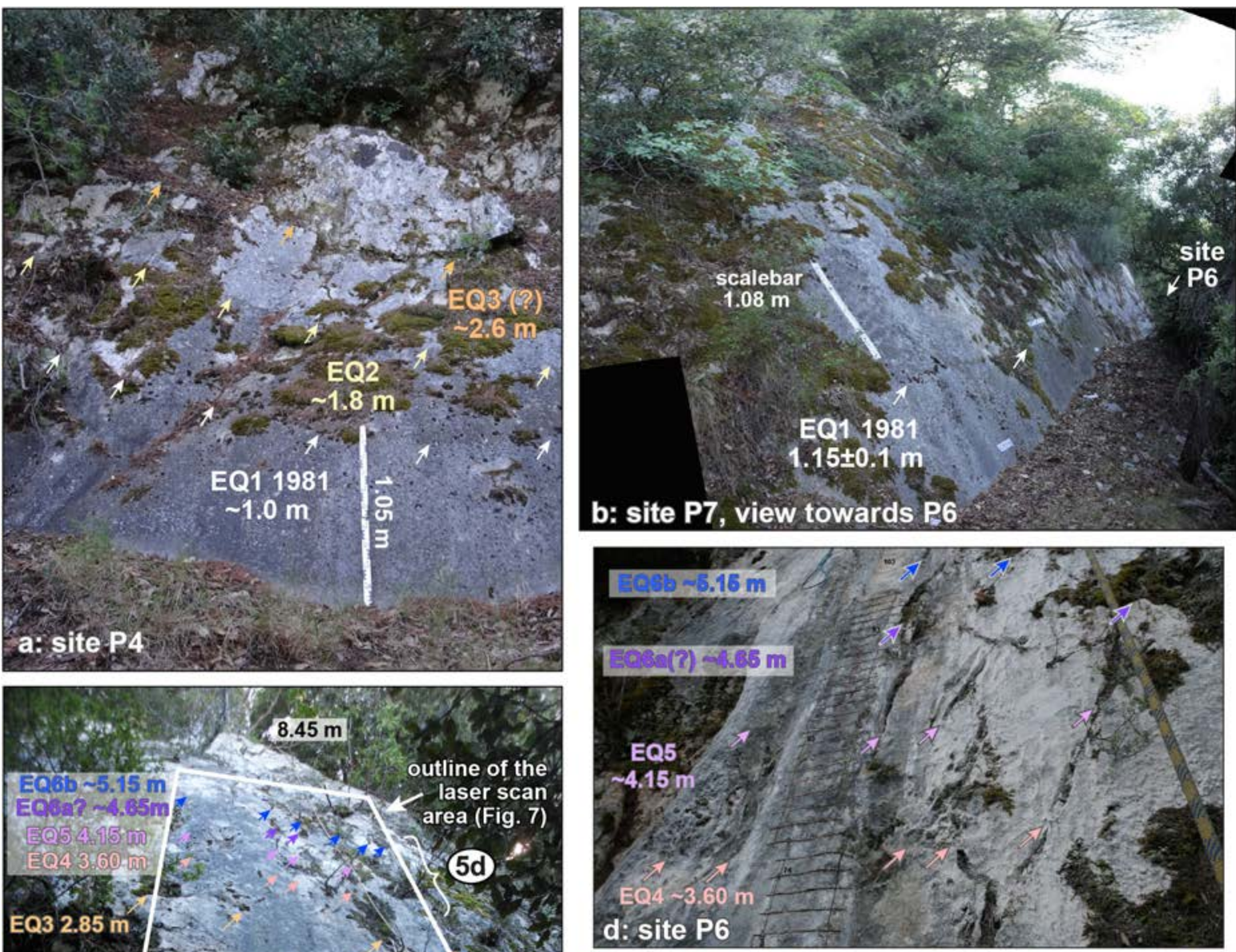

1083
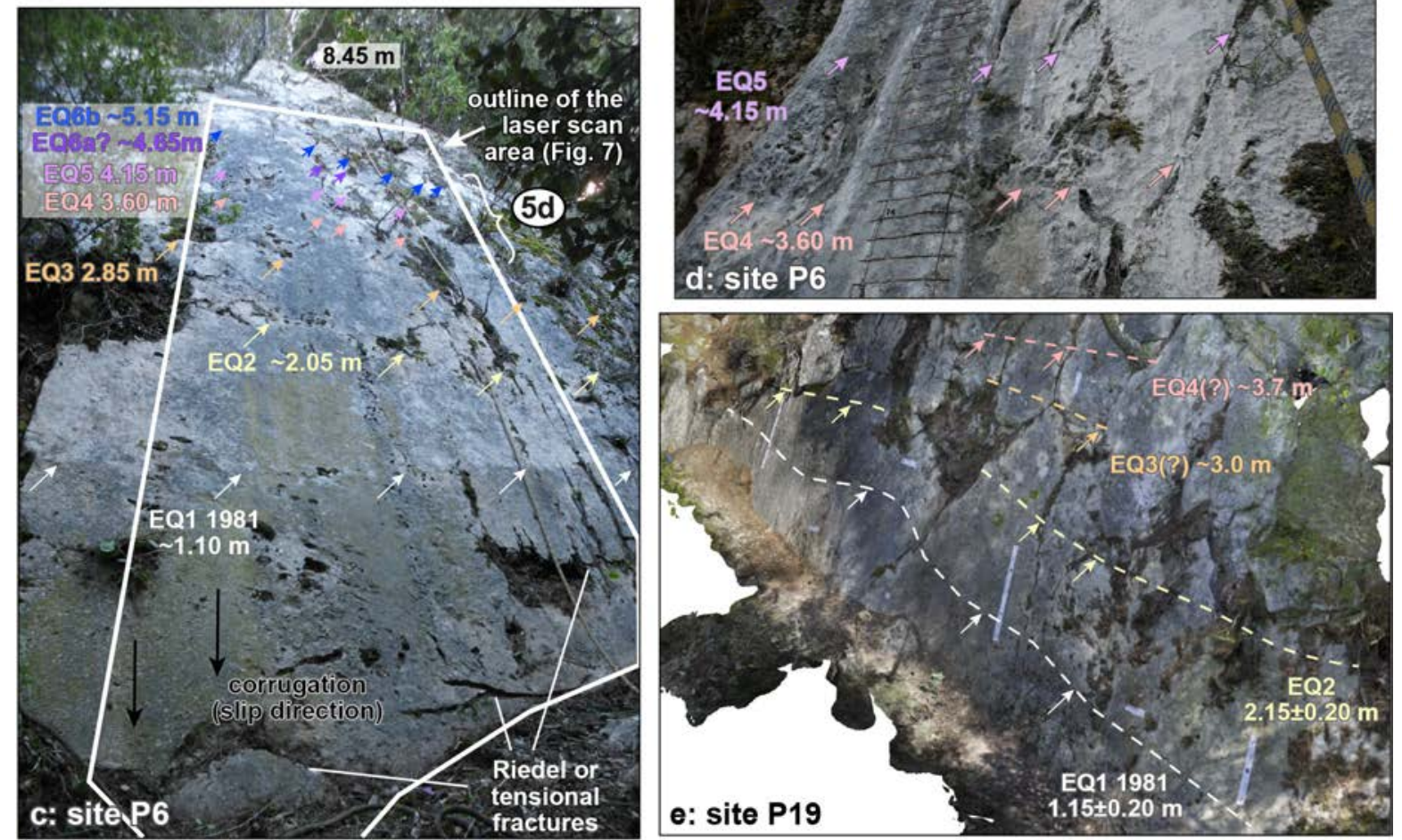

1084

Figure 5

1085

1086 


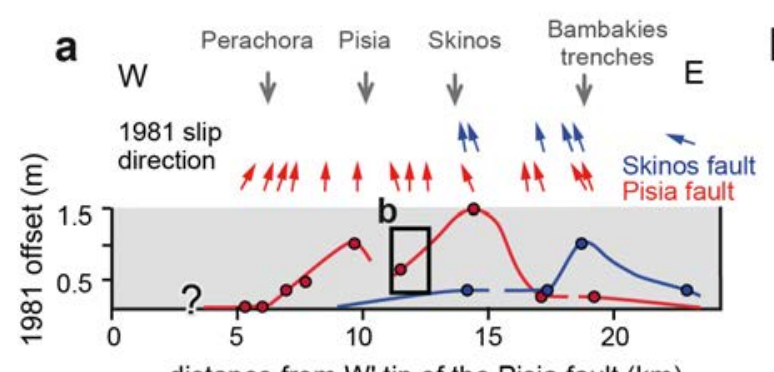

distance from $\mathrm{W}^{\prime}$ tip of the Pisia fault $(\mathrm{km})$

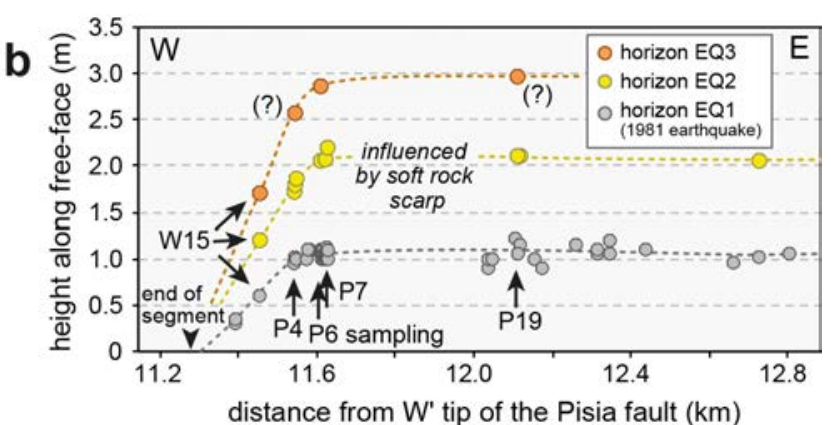

1088 Figure 6 

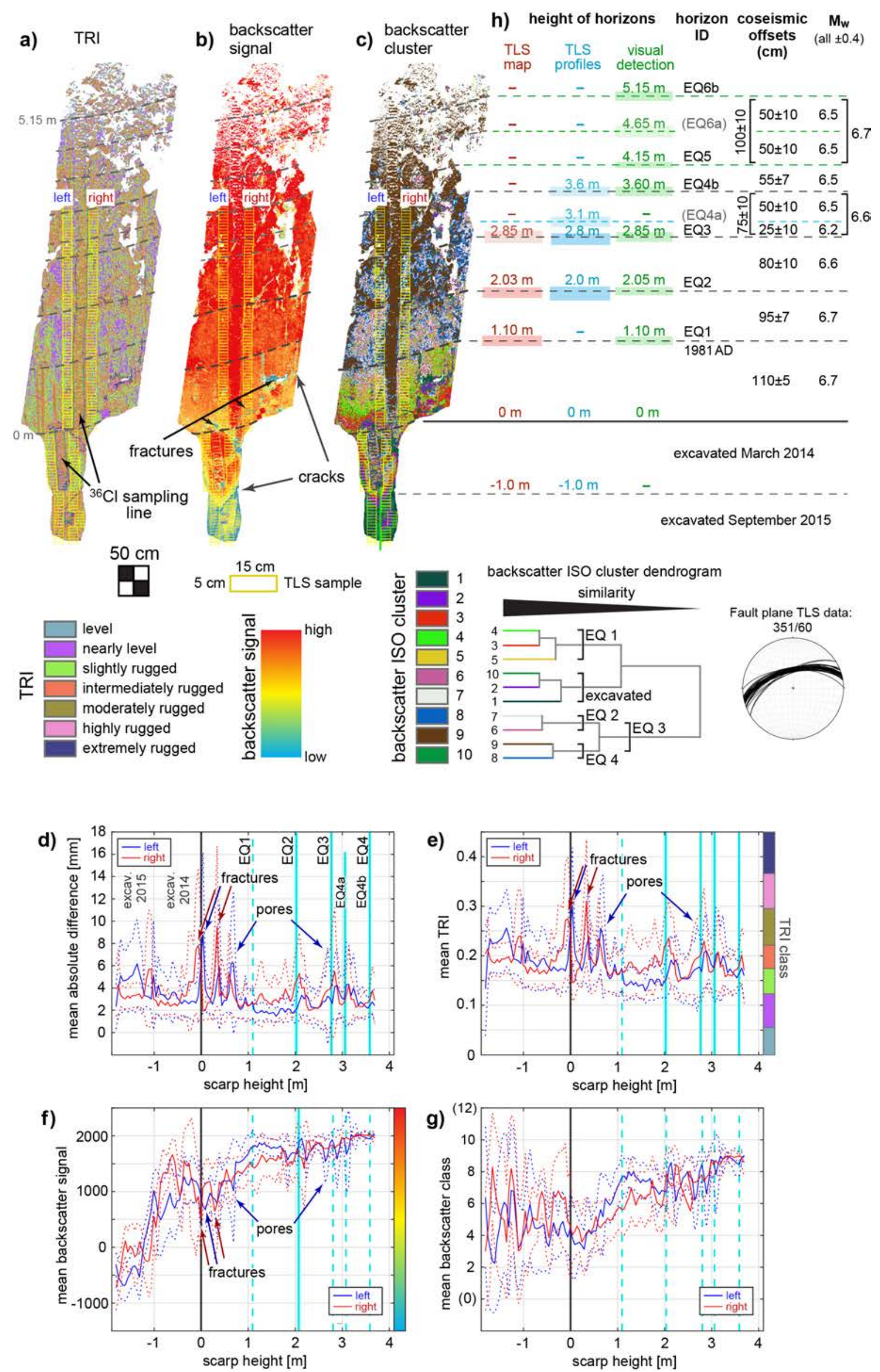

$1090 \quad$ Figure 7 

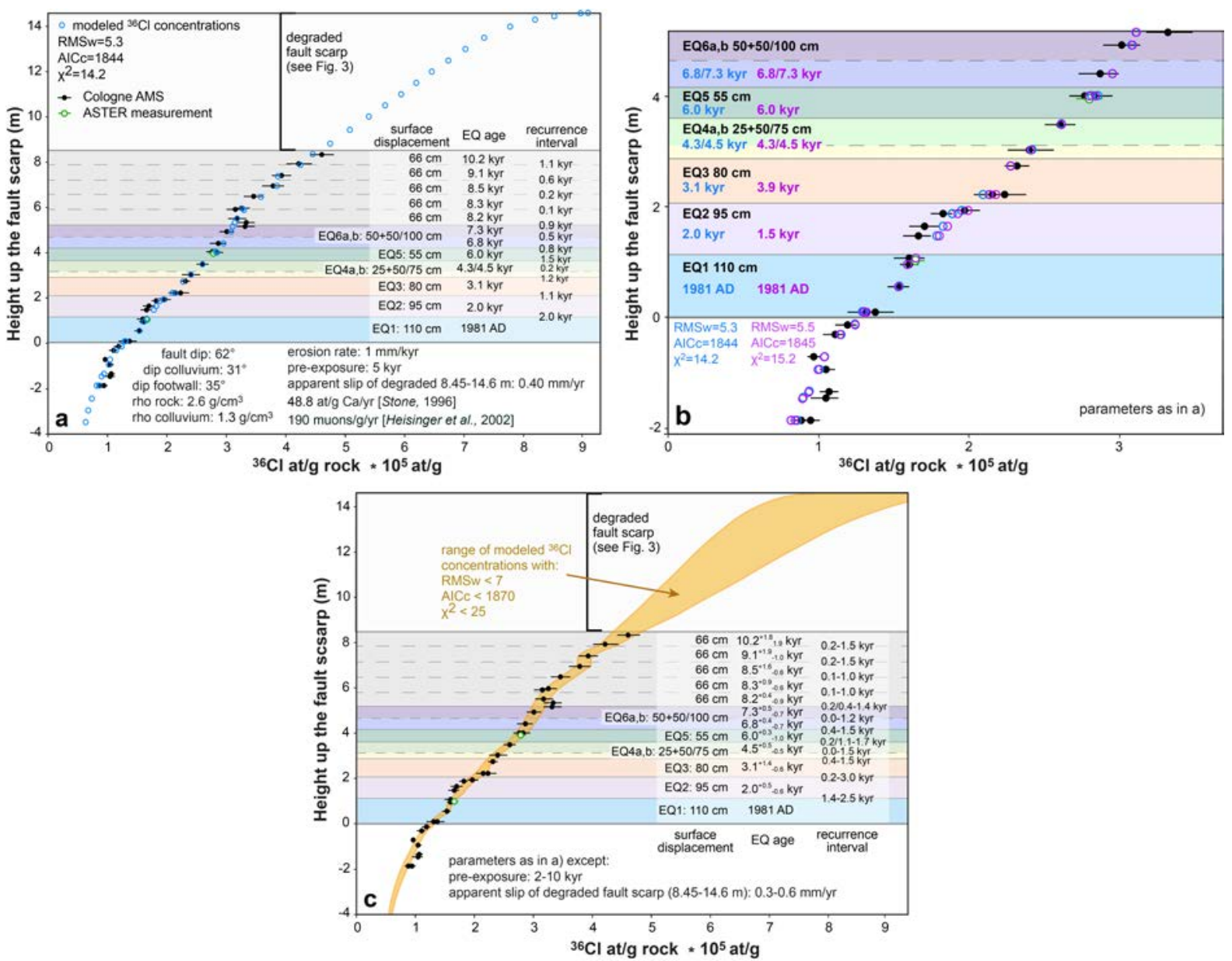

1092 Figure 8 

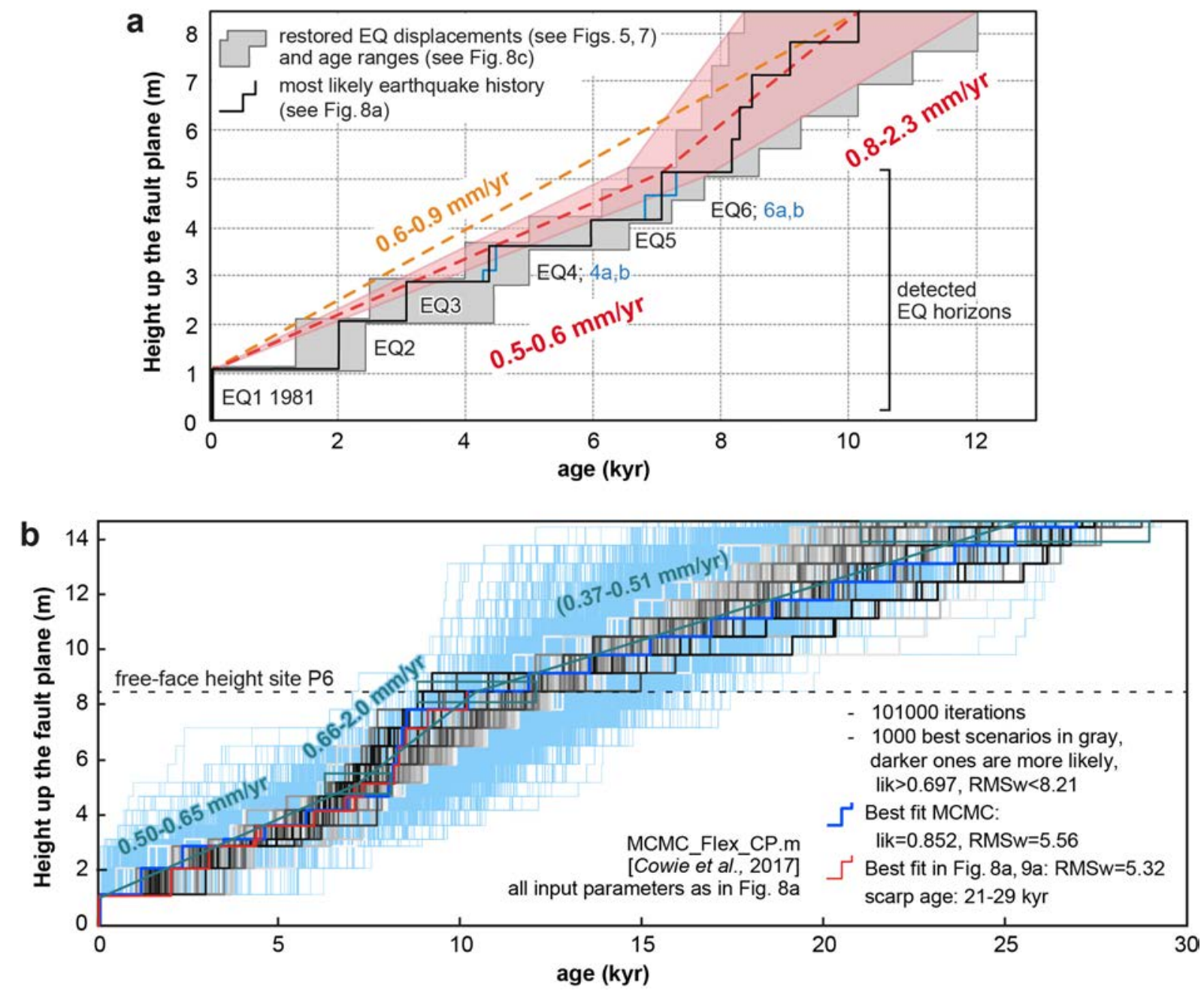

1094

Figure 9 


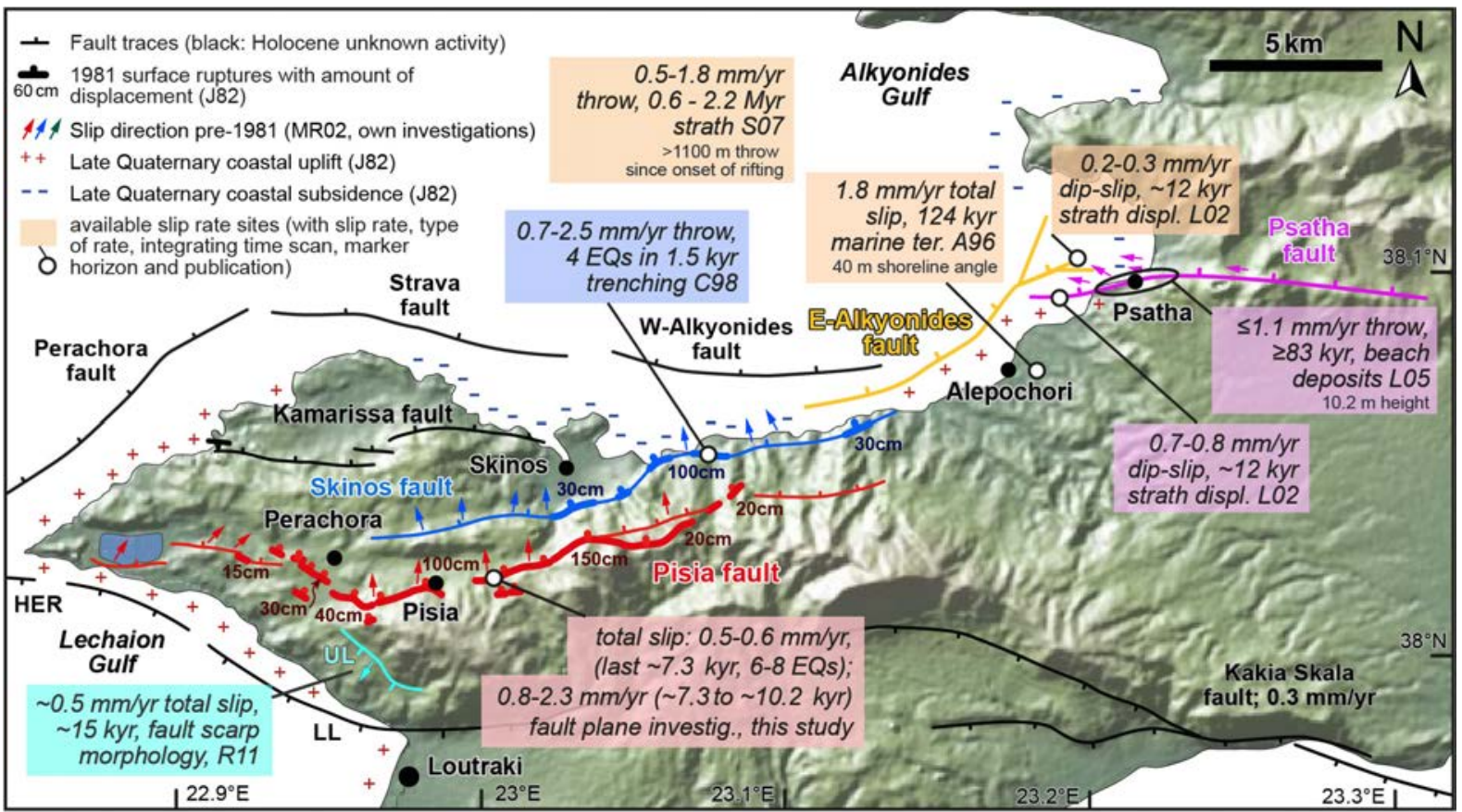

1096 Figure 10 